\title{
Heat treatment of bovine colostrum: II. Effects on calf serum immunoglobulin, insulin, and IGF-I concentrations, and the serum proteome
}

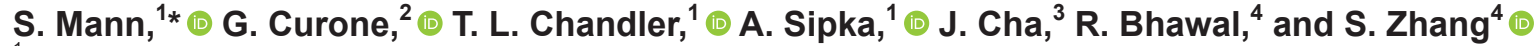 \\ ${ }^{1}$ Department of Population Medicine and Diagnostic Sciences, College of Veterinary Medicine, Cornell University, Ithaca, NY 14853 \\ ${ }^{2}$ Department of Veterinary Medicine, University of Milano, 26900, Lodi, Italy \\ ${ }^{3}$ Division of Nutritional Sciences, College of Human Ecology, Cornell University, Ithaca, NY 14853 \\ ${ }^{4}$ Proteomics and Metabolomics Facility, Institute of Biotechnology, Cornell University, Ithaca, NY 14853
}

\section{ABSTRACT}

In-depth analysis of colostrum components has identified hundreds of proteins, but data are sparse regarding their systemic uptake in the newborn calf. Moreover, heat treatment may influence these colostral components and their absorption. Our objectives were to describe the serum proteome of newborn calves before and after colostrum feeding and the possible effects of colostral heat treatment. Newborn Holstein heifer calves $(\mathrm{n}=22)$ were randomized within pair and fed heat-treated $\left(\mathrm{n}=11 ; 60^{\circ} \mathrm{C}, 60 \mathrm{~min}\right)$ or raw $(\mathrm{n}=11)$ colostrum at $8.5 \%$ of birth body weight by esophageal feeder within $1 \mathrm{~h}$ of birth. After the single colostrum feeding, calves were not fed until after the 8-h time point, when milk was offered free-choice. Blood samples were taken immediately before feeding $(0 \mathrm{~h})$, as well as 4,8 , and $24 \mathrm{~h}$ after feeding. Whole blood packed cell volume (\%), serum Brix percentage, and plasma glucose concentrations were determined for all time points. Plasma insulin and insulin-like growth factor-I concentrations were determined by radioimmunoassay for selected time points. Serum IgA and IgG were measured by radial immunodiffusion at $24 \mathrm{~h}$. The serum proteome was analyzed using nano-scale reverse-phase chromatography and tandem mass spectrometry (nano LC-MS/MS) in 0- and 8-h samples. For proteomics analysis, ratios of results for 8-h to 0-h samples were analyzed with false discovery rate adjustment. For all other outcomes, repeated-measures ANOVA was performed with the fixed effects of group, time, and their interaction, and random effect of pair. Serum Brix percentage and glucose concentrations increased over time and were independent of colostrum treatment. Serum IgG and $\operatorname{IgA}$ concentrations at $24 \mathrm{~h}$ did not differ between groups. Nano LC-MS/MS identified a total of

Received March 30, 2020

Accepted June 2, 2020.

*Corresponding author: sm682@cornell.edu
663 unique proteins in serum, of which 261 increased in abundance, whereas 67 decreased in abundance after feeding in both groups. Among serum proteins that increased in abundance and that were previously identified in colostrum, many belonged to those involved in immune response, coagulation, the classical complement pathway, or the antimicrobial peptide class of cathelicidins. Serum proteins that decreased in abundance and that were identified in colostrum belonged to the alternative complement pathway and the membrane attack complex. Thirty-eight proteins differed in calves that were fed heat-treated colostrum compared with those fed raw colostrum. Decreased abundances in calves fed heat-treated colostrum included several enzymes involved in glycolysis or glycogenolysis, whereas the incretin gastric inhibitory polypeptide and serum insulin were increased in this group. Our findings point to important innate immune defense pathways associated with colostrum ingestion in newborn calves. Furthermore, calves fed heat-treated colostrum showed differences in serum proteins and enzymes associated with carbohydrate metabolism.

Key words: neonate, colostrum, serum proteome, immunology

\section{INTRODUCTION}

Early intake of adequate amounts of high-quality colostrum is critical for the health and growth of the bovine neonate (Godden et al., 2019). Colostrum delivers a concentrated form of nutrients, vitamins, and a plethora of bioactive factors to neonates (Quigley and Drewry, 1998; Hammon et al., 2013). Some colostral components - for example, Ig (Bush and Staley, 1980), maternal leukocytes (Reber et al., 2006), and enzymes such as $\gamma$-glutamyl-transferase (Baumrucker et al., 1994) - are clearly taken up into circulation, particularly in the first hours of life. Other proteins, such as colostral insulin and IGF-I are likely not taken up systemically (Grütter and Blum, 1991; Vacher et al., 
1995) and appear to act locally in the neonatal gut as growth factors (Shulman, 1990; Baumrucker et al., 1994; Steinhoff-Wagner et al., 2011).

Colostral IgG are among the best-characterized proteins that are absorbed into circulation. Defined as successful transfer of passive immunity (TPI), the increase of serum IgG in circulation from intestinal uptake is associated with protection against disease in preweaned calves (Furman-Fratczak et al., 2011). The available body of literature clearly shows that when IgG are not transferred at sufficiently high concentrations shortly after birth (failure of TPI), the risk for morbidity and mortality of preweaning calves increases (McGuire et al., 1976; Stilwell and Carvalho, 2011; Raboisson et al., 2016). In lambs, colostrum feeding was associated with the appearance of low-abundant proteins (LAP) in plasma in addition to Ig (Hernández-Castellano et al., 2014), although the study design did not allow conclusive interpretation regarding the origin of these proteins from intestinal absorption or endogenous production. Few studies are available in the bovine neonate that describe changes in serum protein abundance in response to colostrum feeding. This limits our understanding of possible uptake of LAP with biological significance in the newborn calf.

Heat treatment of colostrum is a well-established management tool that decreases bacterial contamination of colostrum, extends storage after harvest, improves IgG absorption capacity, and can control important infectious agents that can be transmitted to the neonate in colostrum (Godden et al., 2019). A recent study in the United States showed that this practice has been adopted on $8.7 \%$ of 104 dairy operations in 13 states, based on a convenience sampling from 2014 to 2015 (Urie et al., 2018). Prevalence of this practice likely differs regionally and by farm size, and has likely changed since that study was conducted. The advantages of heat treatment have been clearly demonstrated for infectious disease control (Godden et al., 2019). Recent discovery and reconsideration of other colostrum components, such as growth factors (Hammon et al., 2013), maternal leukocytes (Donovan et al., 2007), and proteins specifically enriched in colostrum (Fahey et al., 2020), invite another look at the possible effects of colostral heat treatment on the newborn calf beyond achieving successful TPI.

Tacoma et al. (2017) investigated heat-treatment effects on the colostrum proteome of a single pooled sample, and showed that among the 62 proteins that differed between the heat-treated and the raw sample, 44 were reduced in abundance. In our companion paper, we identified and reported 45 proteins that were decreased by heat treatment of colostrum (Mann et al.,
2020). The potential effects of these findings on the calf were not further investigated by Tacoma et al., (2017). To address this knowledge gap, the objectives of this study were to compare the serum proteome of neonatal calves before and after colostrum feeding, to investigate changes in serum protein abundance after feeding, and to study whether serum protein abundance differed when colostrum was heat-treated before feeding. Furthermore, our companion work, investigating heat-treatment effects on colostrum, showed decreases in colostral IgA, insulin, and IGF-I concentrations in samples that were heat-treated (Mann et al., 2020). We therefore extended our current objectives to examine the possible heat-treatment effects on the circulating concentrations of these analytes in newborn calves fed either raw or heat-treated colostrum.

\section{MATERIALS AND METHODS}

\section{Animals and Colostrum Samples}

All animal procedures were reviewed and approved by the Cornell University Institutional Animal Care and Use Committee (Ithaca, NY; protocol no. 2018-0021). The study was performed between July and August 2018 on a commercial dairy farm in New York State. Harvest of colostrum samples and treatment before feeding are described in detail in our companion paper (Mann et al., 2020). In brief, colostrum of eligible cows was harvested in a 4-stall herringbone parlor (DeLaval International AB, Tumba, Sweden) according to farm protocol within $8 \mathrm{~h}$ following calving. Colostrum of individual cows was milked into clean buckets, and Brix percentage was recorded using a digital refractometer (Palm Abbe, Misco, Cleveland, OH). Colostrum $\geq 22 \%$ Brix and $\geq 8$ L total volume was eligible to be used in the study. Colostrum was mixed and filled into 2 disposable 4-L bags (Perfect Udder, Dairy Tech Inc., Windsor, CO). Raw colostrum was immediately placed on ice for $30 \mathrm{~min}$ and refrigerated at $4^{\circ} \mathrm{C}$ for up to 24 $\mathrm{h}$, whereas the corresponding 4 -L portion of the same colostrum was heat-treated for $60 \mathrm{~min}$ at $60^{\circ} \mathrm{C}$, cooled in the pasteurizer to $43^{\circ} \mathrm{C}$, and then moved to an ice bath for $30 \mathrm{~min}$ before storage at $4^{\circ} \mathrm{C}$ for up to $24 \mathrm{~h}$.

\section{Calves and Colostrum Feeding}

Female Holstein calves born to primi- or multiparous cows and with a birth weight of 34.0 to $47.0 \mathrm{~kg}$, without birth defects, having been delivered without assistance, and showing a normal respiratory pattern, were eligible for enrollment. Calves were enrolled to be fed raw $(\mathbf{R}$; $\mathrm{n}=11)$ or heat-treated $(\mathbf{H} ; \mathrm{n}=11)$ colostrum follow- 
ing a randomized block design with 2 calves per block, according to the time of birth on the same day. Random sequence was produced using a research randomizer (Urbaniak and Plous, 2012). Following standard farm procedures, calves were removed from their dam within 10 min after birth and not allowed to suckle on their dams, weighed on a platform scale (EziWeigh 5i, Tru-Test, Auckland, New Zealand), and moved into a sawdust-bedded pen to dry. Raw or heat-treated colostrum, prepared as described, was adjusted to $8.5 \%$ of the calf's birth BW (Conneely et al., 2014). Bags of refrigerated raw or heat-treated colostrum were then placed in a $43^{\circ} \mathrm{C}$ water bath (MilkWorks, Dairy Tech Inc.) for 20 min to warm to feeding temperature. Colostrum Brix percentage was measured again before feeding, to compare paired colostrum treatments among the 2 bags of a single batch, as well as to compare with Brix percentage recorded immediately after harvest. None of the calves were fed their own dam's colostrum. Colostrum was administered to calves within $1 \mathrm{~h}$ of birth, using an esophageal feeder (Dairy Tech Inc.) according to manufacturer instructions (www.dairytechinc.com) and consistent with farm protocols. Both treatments $(\mathrm{H}$ and R) of a single batch were administered to each pair of newborn calves, on average within $2 \mathrm{~h}$, and within a maximum of $4 \mathrm{~h}$ from each other. All calves were moved to a group-housed pen (20 calves/pen) $8 \mathrm{~h}$ after feeding, where free-choice heat-treated milk was offered ad libitum. Calves were unenrolled from the study after the 24-h sample. Weaning weight was obtained from farm records.

\section{Blood Sampling}

Blood samples were taken from the jugular vein of each calf immediately before colostrum feeding $(0 \mathrm{~h})$, at 4,8 , and $24 \mathrm{~h}$ after feeding. Blood sampling at 0,4 , and $8 \mathrm{~h}$ was performed in box stalls in the maternity pen, whereas the 24-h sampling occurred in the grouphoused pen. Skin overlaying the jugular veins was clipped and disinfected with $70 \%$ ethanol. Blood was collected into evacuated $10-\mathrm{mL}$ tubes with or without EDTA (Monoject, Covidien, Dublin, Ireland). Tubes with EDTA were immediately placed on ice, and serum tubes were allowed to clot at room temperature for 10 min. Serum and EDTA tubes were centrifuged for 20 min at $3,000 \times g$ at $4^{\circ} \mathrm{C}$ within 30 min after collection. Harvested serum and plasma samples were snap-frozen in liquid nitrogen, stored at $-20^{\circ} \mathrm{C}$ for $<24 \mathrm{~h}$, and then stored at $-80^{\circ} \mathrm{C}$ until analysis.

Packed cell volume (PCV) was determined using microhematocrit tubes (Hemato-Clad Plain, Drummond Scientific, Broomall, PA) centrifuged at 3,000 $\times g$ for $10 \mathrm{~min}$ at room temperature and read using a hematocrit reader card (EZ Reader, LW Scientific, Lawrenceville, GA).

\section{Serum Measurements}

Serum Brix percentage was measured with a digital refractometer (Palm Abbe, Misco). Serum total protein (STP) was measured using a handheld 3-scale optical refractometer (Kernco Instruments Company, El Paso, TX). The total amounts of ingested IgG and IgA for each calf were calculated based on results for IgG and IgA concentrations in the colostrum samples reported in our companion paper (Mann et al., 2020) and the amount of colostrum fed at $8.5 \% \mathrm{BW}$ at birth. Concentrations of serum $\operatorname{IgG}$ and $\operatorname{IgA}$ were determined in serum samples obtained $24 \mathrm{~h}$ after first colostrum feeding using radial immunodiffusion (RID) assays (Triple J Farms, Bellingham, WA). All samples were run using assays and controls of the same lot number, and samples of calf pairs were assayed on the same plate. Serum was thawed at room temperature for $30 \mathrm{~min}$ before RID assay. To ensure that serum IgG concentration fell within the range of the standards provided, serum was diluted 2-fold with $0.9 \%$ saline. Samples for IgA were not diluted. For both IgG and IgA RID assay, $5 \mu \mathrm{L}$ of sample was pipetted into duplicate wells. Assay plates were incubated at room temperature for $24 \mathrm{~h}$ and then read using an LED 10× Scale Loupe (TekcoPlus, Kowloon, Hong Kong) and MagniPros LED magnifying glass (South El Monte, CA). Mean and standard deviation (SD) were calculated from duplicates to determine coefficient of variation (CV). Analyses for samples with $\mathrm{CV}>10 \%$ were repeated.

\section{Plasma Insulin, IGF-I, and Glucose Concentrations}

Plasma insulin and IGF-I concentrations were determined at the Endocrinology Laboratory of the Animal Health Diagnostic Center (Cornell University, Ithaca, NY). Insulin was measured via RIA using a rat RIA (RI-13K, MilliporeSigma, Burlington, MA), and IGF-I was measured using an IGF-binding protein-blocked human RIA technique (IGF-I RIA, Mediagnost, Reutlingen, Germany) suitable for heterologous use in bovine samples. Samples were mixed with assay buffer to achieve a final 100-fold dilution. Plasma concentrations of glucose were determined via an enzymatic-colorimetric method (PGO enzyme preparation, Sigma-Aldrich, St. Louis, MO)

\section{Proteomics Analysis}

A total of 20 serum samples at 0 and $8 \mathrm{~h}$ from 5 calf pairs $(H$ and $R$ ) fed colostrum of a single batch 
were treated with complete protease and phosphatase inhibitor (Halt, Thermo Fisher Scientific, Waltham, MA) immediately upon thawing. Depletion of the high-abundance proteins of each sample was achieved using ProteoMiner (Altomare et al., 2016; Tacoma et al., 2017). In brief, ProteoMiner (BioRad, Hercules, CA) bead slurry $(10 \mu \mathrm{L})$ was incubated with $300 \mu \mathrm{L}$ of serum $(\sim 10 \mathrm{mg})$ in $1 \times$ PBS, pH 7.4. Enriched proteins were eluted off ProteoMiner beads with $8 M$ urea, $2 \%$ 3-cholamidopropyldimethylammoniol-propanesulfonate, and 5\% acetic acid. All samples were dried in a Speed-Vac concentrator (Speed Vac SC110, Savant Instruments Inc., Holbrook, NY) to remove acetic acid and reconstituted in $60 \mu \mathrm{L}$ of $0.2 \mathrm{M}$ tetraethylammonium bromide, $\mathrm{pH} 8.5$.

Following ProteoMiner treatment, protein concentration for each sample was determined via bicinchoninic acid assay and further quantified by running a precast $10 \%$ Bis-Tris gel (Invitrogen, Carlsbad, CA) along with a series of Escherichia coli lysates (2.5, 5, 10, or $20 \mu \mathrm{g} /$ lane; Figure 1). The SDS gels were visualized with colloidal Coomassie blue stain (Invitrogen) and imaged via Typhoon 9400 scanner followed by ImageQuant TL 8.1 (GE Healthcare, Chicago, IL) for quantitation analysis. Successful depletion of a highly abundant protein band at 65 to $70 \mathrm{kDa}$, a size consistent with highly abundant albumin, was confirmed on SDS-PAGE (Figure 1).

Further processing of proteins was then performed according to Thermo Fisher Scientific's Tandem Mass Tagging (TMT) Kits and Reagents protocol (http:/ /www.piercenet.com/instructions/2162073.pdf) with modification by Yang et al. (2011). A total of $30 \mu \mathrm{g}$ of protein from each sample was reduced with $20 \mathrm{mM}$ tris(2-carboxyethyl)phosphine for $1 \mathrm{~h}$ at room temperature, alkylated with $20 \mathrm{~m} M$ iodoacetamide for $1 \mathrm{~h}$ in the dark, and then quenched by addition of $20 \mathrm{mM}$ dithiothreitol. The alkylated proteins were precipitated by adding 6 volumes of ice-cold acetone and incubating at $-20^{\circ} \mathrm{C}$ overnight and reconstituted in $50 \mu \mathrm{L}$ of $100 \mathrm{~m} M$ triethylammoniumbicarbonate. Each sample was digested with $1.5 \mu \mathrm{g}$ of trypsin for $18 \mathrm{~h}$ at $35^{\circ} \mathrm{C}$. The TMT 11-plex labels (dried powder) were reconstituted with $25 \mu \mathrm{L}$ of anhydrous acetonitrile (ACN) before labeling and added in a 1:2 ratio to each of the tryptic digest samples for labeling over $1 \mathrm{~h}$ at room temperature; 2 sets of TMT 11-plex were used for labeling 20 samples and each set for 10 samples. The open channel in each set of TMT 11-plex was labeled as the 11th sample, which was a pool of all 20 samples used for bridging the 2 sets of data. After checking label incorporation using Orbitrap Fusion (Thermo Fisher Scientific) by mixing $1-\mu \mathrm{L}$ aliquots from each sample and desalting with SCX ZipTip (Millipore, Bil-

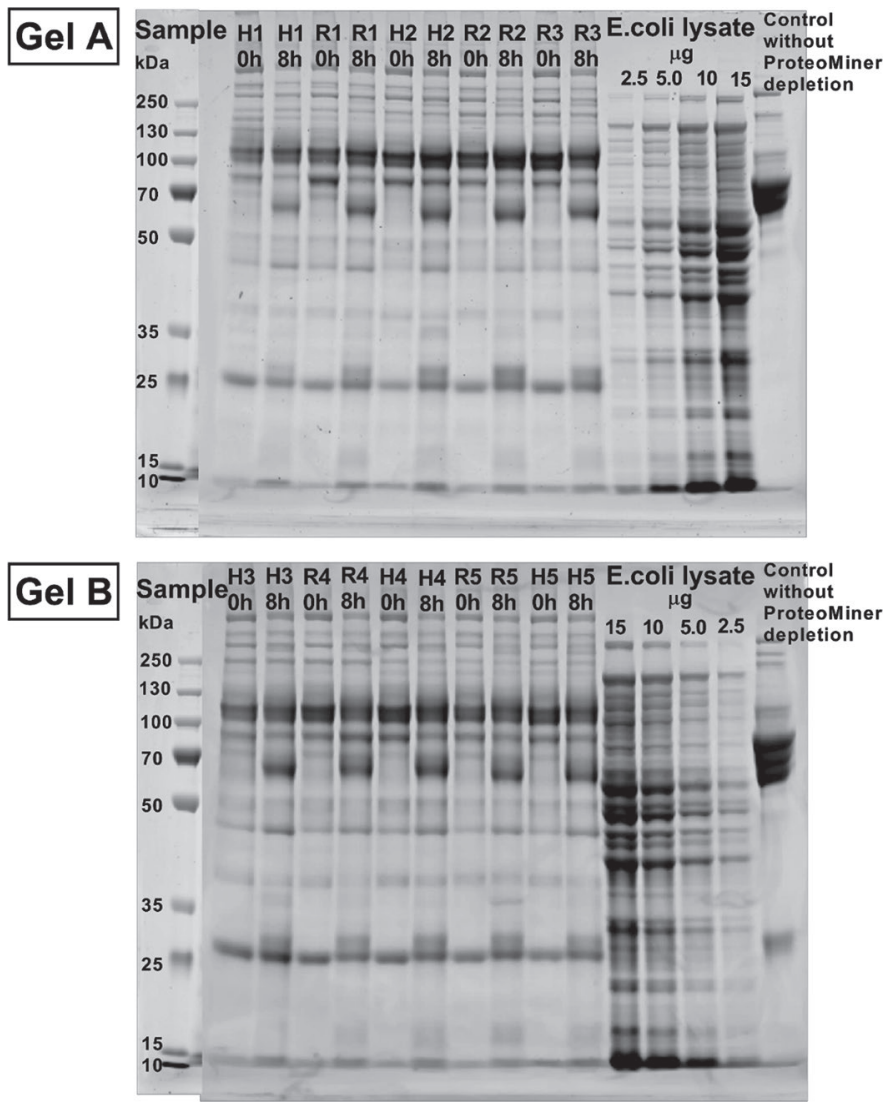

Figure 1. SDS-PAGE gel profiling of the 20 serum samples (10 per gel). Molecular mass ladder on the left; Escherichia coli lysate used for quantification on the right. Loading volume per lane $=6 \mu \mathrm{L}$. $\mathrm{H}=$ heat-treated; $\mathrm{R}=$ raw; $0 \mathrm{~h}=$ before colostrum feeding; $8 \mathrm{~h}=8 \mathrm{~h}$ after colostrum feeding. Stained with colloidal Coomassie blue. Sample on far right shows a sample before ProteoMiner (BioRad, Hercules, CA) depletion for comparison. Escherichia coli lysate standard curve $\mathrm{R}^{2}=$ 0.9969 and 0.9997 for Gel A and B, respectively.

lerica, MA), the 11 labeled peptide samples in each set were pooled together. The pooled peptides of each set were then evaporated to $200 \mu \mathrm{L}$ and subjected to cleanup by solid phase extraction on MCX cartridges (Waters, Milford, MA) for subsequent first-dimensional liquid chromatography (LC) fractionation via high-pH reverse-phase chromatography.

High-pH reverse-phase fractionation was carried out using an UltiMate 3000 HPLC system (Dionex, Sunnyvale, CA) with the built-in micro fraction collection option in its autosampler and UV detection (Thermo Fisher Scientific) as reported previously (Yang et al., 2011). Specifically, the TMT 10-plex tagged tryptic peptides were reconstituted in buffer A (20 mM ammonium formate, $\mathrm{pH} 9.5$ in water), and loaded onto an XTerra MS C18 column $(3.5 \mu \mathrm{m}, 2.1 \times 150 \mathrm{~mm})$ from Waters, with $20 \mathrm{mM}$ ammonium formate $\left(\mathrm{NH}_{4} \mathrm{FA}\right), \mathrm{pH}$ 9.5, as buffer $\mathrm{A}$ and $80 \% \mathrm{ACN} / 20 \% 20 \mathrm{mM} \mathrm{NH} \mathrm{NHA}_{4}$ as 
buffer B. The LC was performed using a gradient from 10 to $45 \%$ of buffer B in $30 \mathrm{~min}$ at a flow rate of 200 $\mu \mathrm{L} / \mathrm{min}$. Forty-eight fractions were collected at $1 \mathrm{~min}$ intervals and pooled into a total of 8 fractions based on UV absorbance at $214 \mathrm{~nm}$ and with multiple fraction concatenation strategy (Yang et al., 2011). Each of the 8 fractions was dried and reconstituted in $100 \mu \mathrm{L}$ of $2 \%$ ACN $/ 0.5 \%$ formic acid (FA) for nano LC-tandem mass spectroscopy (LC-MS/MS) analysis.

\section{Nano-Scale Reverse-Phase Chromatography and Tandem MS (Nano LC-MS/MS)}

The nano LC-MS/MS analysis was carried out using an Orbitrap Fusion (Thermo Fisher Scientific) mass spectrometer equipped with a nanospray Flex Ion Source, using high-energy collision dissociation, similar to previous reports (Yang et al., 2011, 2018; Zhang et al., 2019) and coupled with the UltiMate3000 RSLCnano (Dionex). Each reconstituted fraction $(3 \mu \mathrm{L})$ was injected onto a PepMap C-18 RP nano trap column (3 $\mu \mathrm{m}, 100 \mu \mathrm{m} \times 20 \mathrm{~mm}$; Dionex) at $15 \mu \mathrm{L} / \mathrm{min}$ flow rate for on-line desalting, and separated on a PepMap C-18 $\mathrm{RP}$ nano column $(2 \mu \mathrm{m}, 75 \mu \mathrm{m} \times 25 \mathrm{~cm})$. The labeled peptides were eluted in a 120-min gradient of $4 \%$ to $35 \%$ ACN in $0.1 \%$ formic acid at $300 \mathrm{~nL} / \mathrm{min}$, followed by an 8-min ramping to $95 \% \mathrm{ACN} / 0.1 \% \mathrm{FA}$ and a 9 -min hold at $95 \% \mathrm{ACN} / 0.1 \% \mathrm{FA}$. The column was re-equilibrated with $2 \% \mathrm{ACN} / 0.1 \% \mathrm{FA}$ for $25 \mathrm{~min}$ before the next run. The Orbitrap Fusion was operated in positive ion mode with nano spray voltage set at $2.1 \mathrm{kV}$ and source temperature at $275^{\circ} \mathrm{C}$. External calibration for Fourier transform, ion trap, and quadrupole mass analyzers was performed. For global proteomics fractions, the instrument was operated in data-dependent acquisition mode using Fourier transform mass analyzer for 1 survey MS scan for selecting precursor ions, followed by 3 -s "Top Speed" data-dependent high-energy collision dissociation MS/MS scans for precursor peptides with 2 to 8 charged ions above a threshold ion count of 20,000, with normalized collision energy of $40 \%$. Mass spectrometry survey scans were performed at a resolving power of 120,000 (full width at half maximum at $\mathrm{m} / z$ 200) for the mass range of $m / z 400$ to 1,600 with automatic gain control $=4 \mathrm{e} 5$ and $\max$ ion trap $=50 \mathrm{~ms}$, and MS/MS scans at 60,000 resolving power with automatic gain control $=1 \mathrm{e} 5$, max ion trap $=86 \mathrm{~ms}$, and quadrupole isolation window $(\mathrm{m} / \mathrm{z})$ at 1.6 for the mass range $\mathrm{m} / \mathrm{z}$ 105 to 2,000. Dynamic exclusion parameters were set at 1 within 50 -s exclusion duration with $\pm 10 \mathrm{ppm}$ exclusion mass width. All data were acquired using Xcalibur 3.0 operation software and Orbitrap Fusion Tune 3.0 (Thermo Fisher Scientific).

\section{Data Processing, Protein Identification, and Data Analysis}

All MS and MS/MS raw spectra from each set of TMT-plex experiments were processed and searched using Sequest HT software within the Proteome Discoverer 2.3 (PD 2.3, Thermo Fisher Scientific). The Bos taurus NCBI 2019 database (https://www.ncbi.nlm.nih .gov/) containing 41,064 sequence entries was used for database searches. The default search settings used for TMT quantitative processing and protein identification in PD 2.3 searching software were as follows: 2 miscleavage for full trypsin with fixed carbamidomethyl modification of cysteine, fixed 6-plex TMT modifications on lysine and N-terminal amines and variable modifications of methionine oxidation, and deamidation on asparagines or glutamine residues and acetylation of protein $\mathrm{N}$ terminus. The peptide mass tolerance and fragment mass tolerance values were $10 \mathrm{ppm}$ and $50 \mathrm{mDa}$, respectively. Identified peptides were filtered for maximum $1 \%$ false discovery rate using the Percolator algorithm in PD 2.3, with additional peptide confidence set to high and peptide mass accuracy $\leq 5 \mathrm{ppm}$. The TMT 11-plex quantification method within PD 2.3 software was used to calculate the reporter ratios with mass tolerance $\pm 10 \mathrm{ppm}$, applying isotopic correction factors. Only peptide spectra containing all reporter ions were designated as "quantifiable spectra" and used for peptide and protein quantitation. A protein ratio was expressed as a median value of the ratios for all quantifiable spectra of the unique peptides pertaining to that protein. A precursor co-isolation filter of $50 \%$ was also applied for minimizing ratio compression caused by co-isolation of precursor ions. For normalization, total peptide amount was used, and scaling mode was applied based on the average of all control samples (pooled sample of all 20 samples). Only proteins that were detected in all samples were further considered.

\section{Statistical Analysis}

No prior studies in calves were available for sample size determination. We based our sample size on previous proteomics research in lambs to detect LAP (Hernández-Castellano et al., 2015). We inflated the sample size by $25 \%$ to 5 calves in each group for the proteomics objective. The larger sample size of 22 animals was based on an expected difference in insulin concentrations by at least $25 \mu \mathrm{IU} / \mathrm{mL}$ and an $\mathrm{SD}$ of 15 $\mu \mathrm{IU} / \mathrm{mL}$ and restricting both type I and type II error to 0.05 , yielding 11 animals in each group.

Outcomes of the experiment were differences between groups for indicators of TPI, glucose, IGF-I, and insu- 
lin concentrations, as well as serum proteome before and after colostrum feeding. Before analysis, serum concentrations were corrected for PCV by adjusting all measured analytes to PCV of $34 \%$ (population mean across all time points). Pairwise correlation of serum measurements, Brix percentage, STP, IgG, and IgA were computed using Proc CORR (SAS v. 9.4, SAS Institute Inc., Cary, NC). For differences in PCV, serum Brix and refractometer readings, as well as glucose, IGF-I, and insulin measurements, repeated-measures ANOVA was performed with the fixed effects of group, time, and their interaction, repeated effect of calf, and random effect of pair to control for the paired sample design. The differences between groups for total IgG and $\operatorname{IgA}$ fed, and $\operatorname{IgG}$ and $\operatorname{IgA}$ concentrations in serum at $24 \mathrm{~h}$, were analyzed accordingly without the repeated effect. All data are presented as least squares means \pm standard error unless otherwise specified. To fulfill model assumptions of residual normality and homoscedasticity, insulin concentrations were log-transformed, and data are presented as back-transformed geometric means and 95\% confidence interval. Differences in pairwise comparisons were performed using Tukey's post hoc procedure to correct for multiple comparisons.

To account for paired data in proteomics analysis, ratios of results for $8 \mathrm{~h}$ to $0 \mathrm{~h}$ samples were first calculated for each calf. Data were then uploaded into MetaboAnalyst v. 4.0 software (Chong et al., 2018), and fold changes and $t$-tests adjusted for false discovery rate for protein ratios were analyzed. No filtering was applied, data were log-transformed, and Pareto scaling was applied to achieve normalization. Box plots and kernel density plots were visually assessed for normality after transformation and scaling. Settings for analysis were as follows: paired fold change analysis, at least 1.5 -fold change in at least 3 out of 5 pairs; paired $t$ tests, $P$-value (adjusted for false discovery rate) $\leq 0.01$.

To investigate the possible interaction effect of time and treatment, a 2-way ANOVA was performed and a heatmap created for all $P<0.05$ features from this analysis. Euclidean distance measure and Ward clustering algorithm were chosen to produce clustering in MetaboAnalyst 4.0 software. Furthermore, a principal components analysis showing the scores was used to produce visualization of patterns for the 2 experimental factors. All figures were generated in MetaboAnalyst v. 4.0 .

\section{RESULTS}

\section{Study Population}

In this study, $8,5,3$, and 6 calves were born to dams of parity $1,2,3$, and 4 , respectively. Birth BW in groups $\mathrm{H}$ and $\mathrm{R}$ were $39.0 \pm 2.9$ and $40.3 \pm 4.5 \mathrm{~kg}$ $(P=0.37)$. Consequently, the amounts of colostrum fed to $\mathrm{H}$ and $\mathrm{R}$ calves at $8.5 \%$ of birth $\mathrm{BW}$ were 3.31 \pm 0.10 and $3.43 \pm 0.10 \mathrm{~kg}$, respectively $(P=0.39)$. Two calves in group $\mathrm{H}$ were sold as replacement heifers before weaning. Weaning weights at the target of $64 \pm$ $3 \mathrm{~d}$ of life for the remaining 20 calves were $90.3 \pm 3.6$ and $89.8 \pm 3.3 \mathrm{~kg}$ in $\mathrm{H}$ and $\mathrm{R}$ groups, respectively $(P=$ $0.91)$. Average daily gains in the preweaning period in groups $\mathrm{H}$ and $\mathrm{R}$ were $0.79 \pm 0.22$ and $0.76 \pm 0.13 \mathrm{~kg} / \mathrm{d}$, respectively $(P=0.66)$.

\section{PCV, Refractometer, and Immunoglobulins}

The PCV, glucose, serum Brix percentage, and STP estimates for all 48 sampling time points are presented in Figure 2. Intra- and inter-assay CV for serum glucose were 5.6 and $9.4 \%$, respectively. Colostrum Brix percentage was not different $(P=0.47)$ at feeding compared with time of harvest (average change, \pm SD: 0.07 $\pm 0.50 \%)$, and aliquots within the same batch had a $0.09 \pm 0.33 \%$ difference in Brix percentage $(P=0.11)$. Total amounts of IgG fed were $356 \pm 36$ and $373 \pm 36$ $\mathrm{g}$ in groups $\mathrm{H}$ and $\mathrm{R}$, respectively $(P=0.54)$. Total amounts of $\operatorname{IgA}$ fed were $16.0 \pm 1.7$ and $19.0 \pm 1.6 \mathrm{~g}$ in groups $\mathrm{H}$ and $\mathrm{R}$, respectively $(P=0.01)$.

Serum Brix measurements before colostrum feeding were $7.49 \pm 0.38$ and $7.26 \pm 0.47 \%$ in groups $\mathrm{H}$ and $\mathrm{R}$, respectively $(P=0.23)$. Correlations between serum Brix percentage, STP $(\mathrm{mg} / \mathrm{dL})$, and serum IgG $(\mathrm{mg} /$ $\mathrm{mL})$ and $\operatorname{IgA}(\mathrm{mg} / \mathrm{mL})$ are presented in Table 1. Serum IgG and IgA $24 \mathrm{~h}$ after feeding of colostrum in the 22 calves did not differ $(P>0.27)$ between paired treatment groups (Figure 3).

\section{Insulin and IGF-I}

Insulin concentrations changed over time, peaking in both groups at $4 \mathrm{~h}$ (Figure 4 ). Groups differed at $8 \mathrm{~h}$ due to a slower decline in insulin in group $\mathrm{H}$ compared with R. The concentration of IGF-I increased from 0 to $8 \mathrm{~h}(145.4 \pm 11.0$ to $178.8 \pm 11.1 \mathrm{ng} / \mathrm{mL}$, respectively; $P<0.001$ ), and by an average of $10.7 \%$ between paired samples, but no difference $(P=0.80)$ was detected between groups (Figure 4).

\section{Results of Proteomics Analysis}

A total of 663 unique proteins were detected in all 20 samples analyzed from 10 calves and in the 2 pooled controls. In the paired analysis of protein ratios from 8 to $0 \mathrm{~h}$, investigating the effects of feeding heat-treated colostrum compared with raw, 38 proteins with at least a 1.5-fold change in a minimum of 3 calf pairs were 


\section{$\theta$ Heat - Raw}
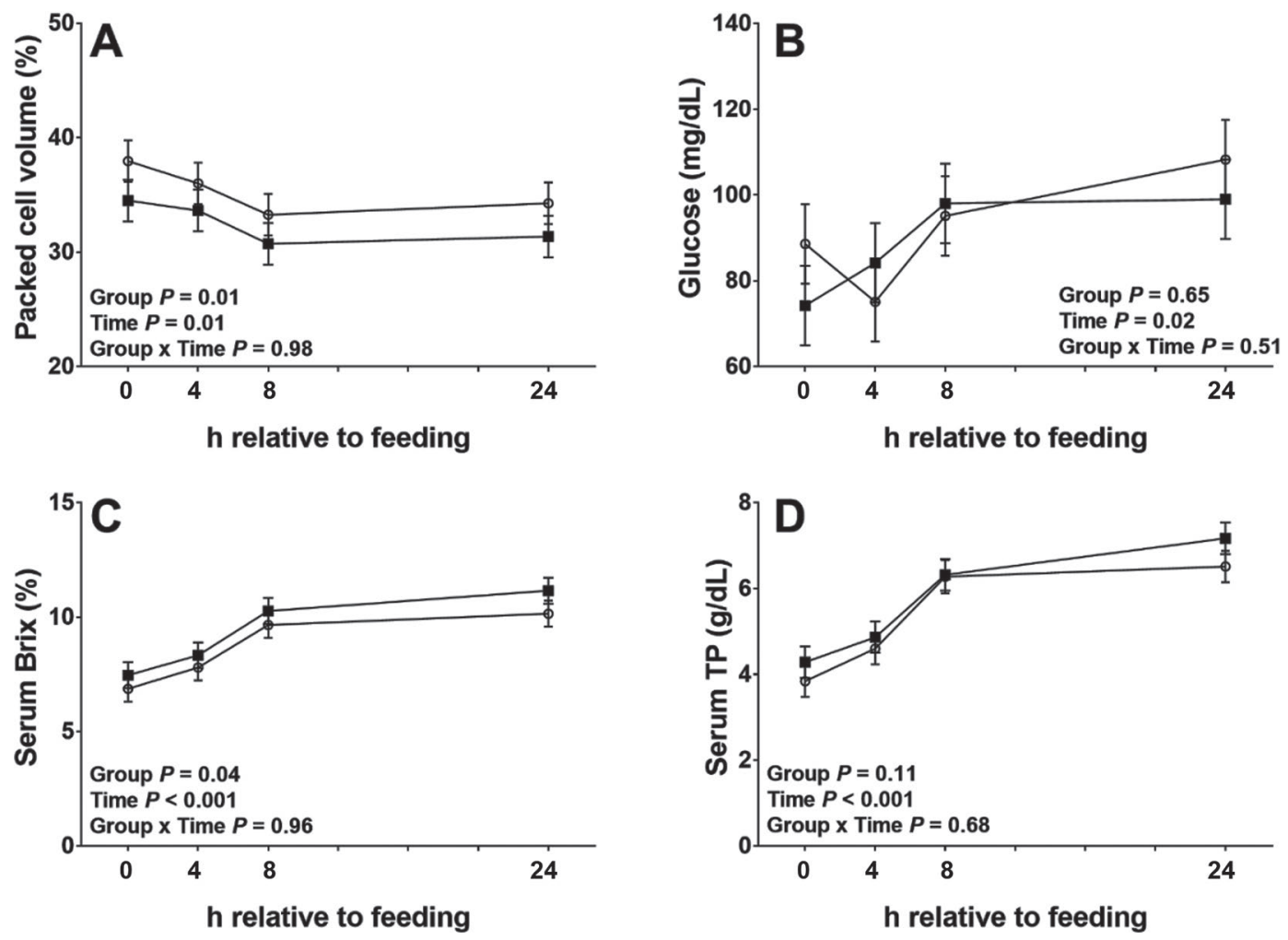

Figure 2. LSM and SE of packed cell volume determined by centrifugation (\%; A), serum glucose concentration (mg/dL; B), Brix digital refractometry $(\% ; \mathbf{C})$, and serum total protein $(\mathrm{TP})$ estimation by refractometry $(\mathrm{g} / \mathrm{dL} ; \mathbf{D})$ measurements of 11 pairs of calves fed either heattreated $\left(60^{\circ} \mathrm{C}, 60 \mathrm{~min}\right.$; Heat) or raw (Raw) colostrum. Mixed-effects ANOVA with fixed effects of time and treatment and their interaction, and random effect of pair.

detected (Figure 5). To annotate identified proteins in all tables, the protein name was entered into the UniProt search function (www.uniprot.org) and biological function extracted for each protein. Proteins were subsequently grouped according to overlapping functions.

Table 1. Pearson correlation matrix for serum Brix percentage and estimated serum total protein (STP) measured by refractometry, as well as IgG and IgA concentrations measured by radial immunodiffusion technique in calf serum samples $(\mathrm{n}=22) 24 \mathrm{~h}$ after colostrum feeding

\begin{tabular}{|c|c|c|c|c|}
\hline Variable & $\begin{array}{c}\text { Serum } \\
\text { Brix }(\%)\end{array}$ & $\begin{array}{l}\text { STP } \\
(\mathrm{g} / \mathrm{dL})\end{array}$ & $\begin{array}{l}\operatorname{IgG} \\
(\mathrm{g} / \mathrm{L})\end{array}$ & $\begin{array}{c}\operatorname{IgA} \\
(\mathrm{g} / \mathrm{L})\end{array}$ \\
\hline \multicolumn{5}{|c|}{ Serum Brix } \\
\hline & 1.0 & 0.99 & 0.61 & 0.58 \\
\hline$P$-value & & $<0.0001$ & 0.003 & 0.004 \\
\hline \multicolumn{5}{|l|}{ STP } \\
\hline & & 1.0 & 0.67 & 0.59 \\
\hline$P$-value & & & 0.007 & 0.004 \\
\hline \multicolumn{5}{|l|}{$\operatorname{IgG}$} \\
\hline $\mathrm{r}$ & & & 1.0 & 0.47 \\
\hline$P$-value & & & & 0.03 \\
\hline
\end{tabular}

In the 2-way ANOVA, no interactions were detected between time and treatment effects $(P<0.05)$ for proteomics data; however, a large number of proteins changed in abundance between the 0 - and 8-h time points, indicating a substantial change in the proteome after colostrum feeding (Figure 6). This is also reflected by time clustering in the principal components analysis, which accounted for the greatest proportion of the variability (Figure 7 ). Features that changed over time included 264 proteins that increased (Table 2) and 67 proteins that decreased in abundance from 0 to $8 \mathrm{~h}$ (Table 3). Proteins that differed over time were compared with the proteins identified in proteomics analysis of the same colostrum sampled and fed to calves in this study (Mann et al., 2020). Among the 261 identified proteins that increased in abundance after colostrum feeding compared with before feeding, 108 (41.4\%) had previously been found in the colostrum samples (Table 2 ). Of the 67 proteins that decreased in abundance over the same time, $32(47.8 \%)$ had also previously been detected in colostrum (Table 3). 

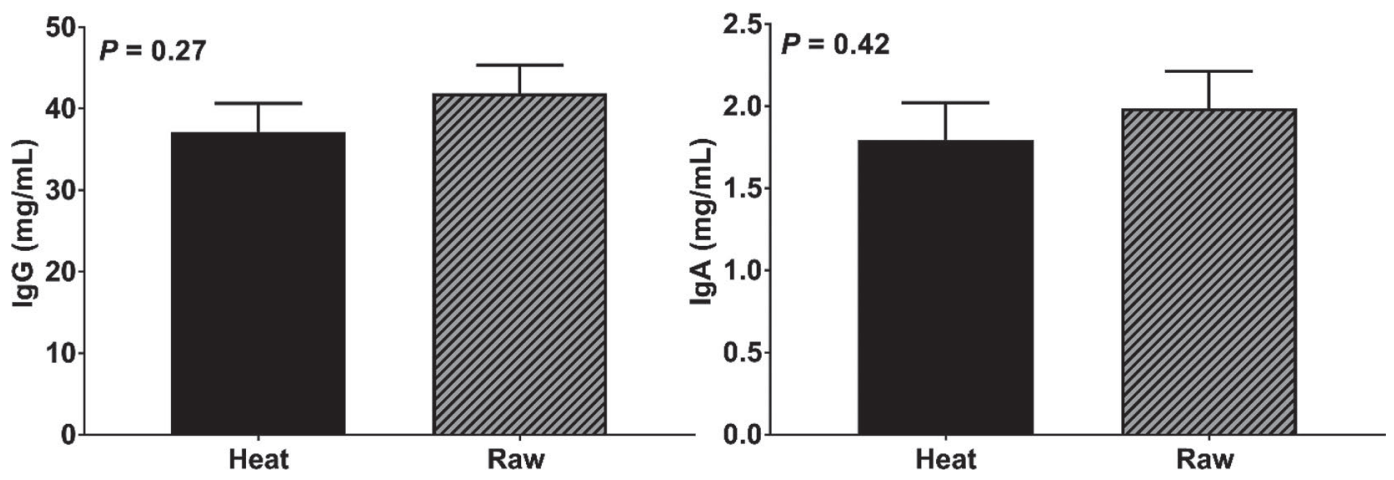

Figure 3. LSM and SE of serum IgG (left) and IgA (right) concentrations $(\mathrm{mg} / \mathrm{mL}) 24 \mathrm{~h}$ after colostrum feeding in 11 pairs of calves fed either heat-treated (Heat; $60^{\circ} \mathrm{C}, 60 \mathrm{~min}$ ) or raw (Raw) colostrum that was cooled immediately after harvest. Mixed-effects ANOVA with fixed effect of treatment and random effect of pair. $P$-value given for difference between groups.

\section{DISCUSSION}

The objective of this study was to determine changes in IgG and IgA transfer, insulin and IGF-I concentrations, and the serum proteome of neonatal calves before and $8 \mathrm{~h}$ after colostrum feeding. The possible influence of heat treatment of colostrum before feeding on the serum proteomes of the calves was investigated. Furthermore, we evaluated possible changes in Ig uptake and growth factor concentrations between calves fed heat-treated or raw colostrum, because changes in these proteins were observed in colostrum associated with heat treatment and reported in our companion study (Mann et al., 2020).

Regardless of colostrum treatment, all calves surpassed the threshold for successful TPI at $24 \mathrm{~h}$, defined as IgG concentrations above $10 \mathrm{mg} / \mathrm{mL}$ (Godden et al., 2019). This is likely due to the timing of feeding within an hour after birth, as well as the high quality, low bac- terial counts, and sufficient quantity of colostrum fed to calves (McGuirk and Collins, 2004). With a targeted colostrum intake of $8.5 \%$ of BW, an amount shown to be associated with optimal IgG absorption (Conneely et al., 2014), calves in this study were fed over 300 $\mathrm{g}$ of IgG. Although sample size was smaller in this study, lack of difference between treatments for IgG, $\operatorname{IgA}$, and refractometer results is consistent with the recent literature, especially when feeding high-quality colostrum with low numbers of bacteria (Gelsinger and Heinrichs, 2017). Previous studies identified an increase in neonatal IgG absorption from colostrum when it was heat-treated (Johnson et al., 2007; Elizondo-Salazar and Heinrichs, 2009), but numbers of bacteria in raw colostrum were higher than in our current study. The absence of a difference in IgA concentrations when calves were fed raw versus heat-treated colostrum is consistent with findings by Johnson et al. (2007), and the median decline of $8.5 \%$ observed in heat-treated
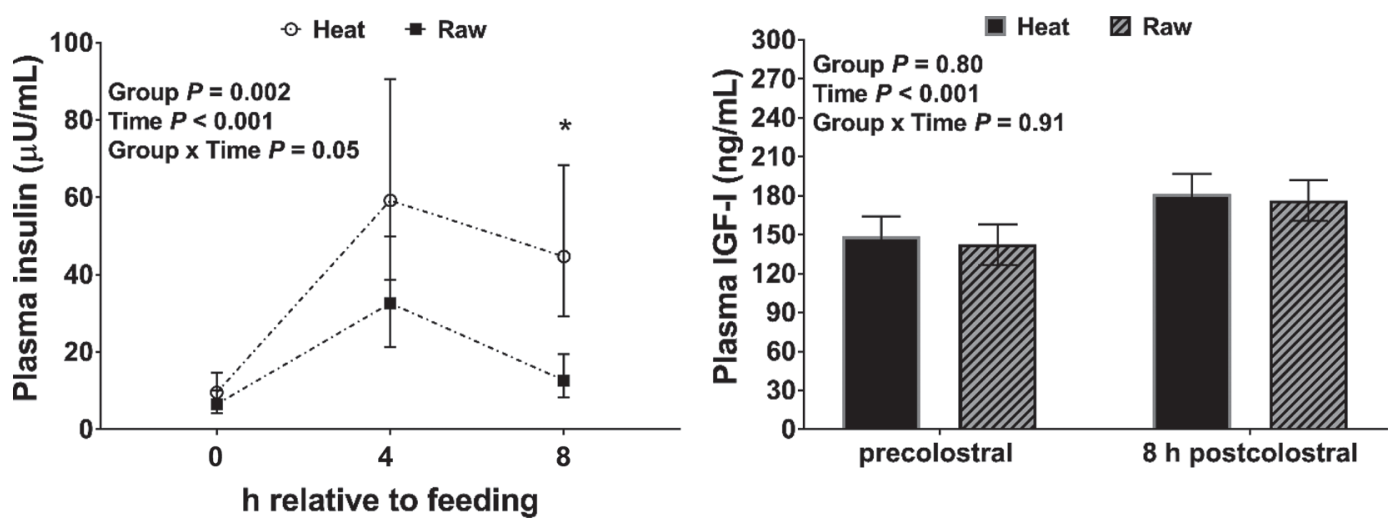

Figure 4. Insulin and IGF-I concentrations in plasma of neonatal calves $(\mathrm{n}=22)$ pair-fed colostrum at $8.5 \%$ of BW, either heat-treated (Heat; $\mathrm{n}=11$ ) or raw (Raw; $\mathrm{n}=11)$. Left: plasma insulin concentration immediately before feeding $(0 \mathrm{~h})$ and 4 and $8 \mathrm{~h}$ after feeding. Backtransformed means and 95\% CI are presented. Right: plasma IGF-I concentration immediately before feeding (precolostral) and $8 \mathrm{~h}$ after feeding (postcolostral). LSM and SE are presented. Mixed-effects ANOVA with fixed effects of time and treatment and their interaction, and random effect of pair. *denotes difference at $P<0.05$ between groups after controlling all pairwise comparisons using Tukey's post hoc test. 
Number of pairs with fold change $\geq 1.5$

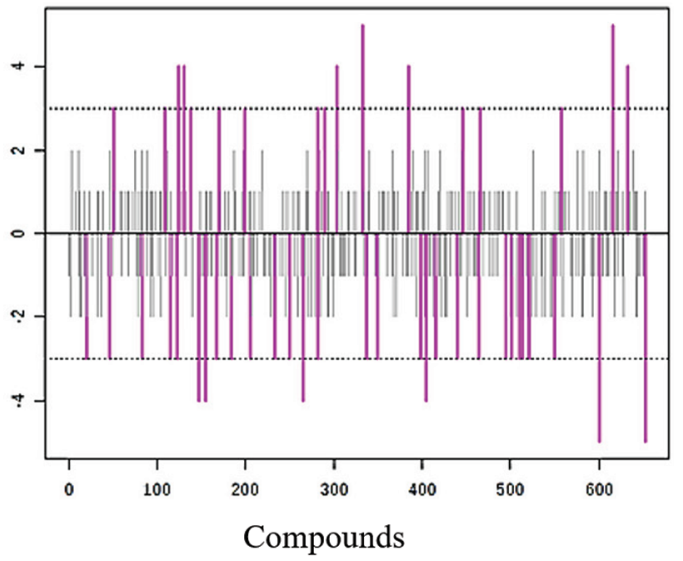

\begin{tabular}{|c|c|c|c|c|}
\hline Biological function & Protein & $\begin{array}{c}\text { Pairs } \\
\text { decreased ratio } \\
\text { H vs. } \mathbf{R} \\
\end{array}$ & $\begin{array}{l}\text { Pairs increased } \\
\text { ratio H vs. R }\end{array}$ & $\begin{array}{l}\text { Identified in } \\
\text { colostrum }\end{array}$ \\
\hline \multirow[t]{7}{*}{ Enzyme } & Aldehyde dehydrogenase, mitochondrial precursor & 4 & 0 & \\
\hline & Glycogen phosphorylase & 3 & 0 & \\
\hline & Malate dehydrogenase, peroxisomal isoform MDH1x & 5 & 0 & \\
\hline & Phosphoglycerate kinase 1 & 4 & 0 & $\mathrm{x}$ \\
\hline & Protein disulfide-isomerase $\mathrm{A} 6$ precursor & 4 & 0 & \\
\hline & Transketolase & 3 & 0 & $\mathrm{X}$ \\
\hline & Triosephosphate isomerase & 3 & 0 & $\mathrm{X}$ \\
\hline \multirow[t]{3}{*}{ Immune response } & Chitinase-3-like protein 1 precursor & 3 & 0 & $\mathrm{X}$ \\
\hline & Fibrinogen $\gamma$-B chain isoform $\mathrm{X} 1$ (predicted) & 3 & 0 & $\mathrm{X}$ \\
\hline & Fibrinogen $\beta$ chain precursor & 3 & 0 & $\mathrm{X}$ \\
\hline \multirow[t]{3}{*}{ Cell motility/adhesion } & Actin-related protein 3 & 3 & 0 & \\
\hline & Laminin subunit $\gamma-1$ precursor & 3 & 0 & $\mathrm{X}$ \\
\hline & Lamin isoform X1 (predicted) & 3 & 0 & \\
\hline Cell differentiation & Suprabasin isoform X4 (predicted) & 5 & 0 & \\
\hline \multirow[t]{2}{*}{ Transport: Protein } & Exportin-2 & 3 & 0 & \\
\hline & rab GDP dissociation inhibitor $\beta$ & 4 & 0 & \\
\hline Transport: Iron & Hemopexin precursor & 3 & 0 & $\mathrm{X}$ \\
\hline Protein folding/ER stress & Binding immunoglobulin protein (BiP) (GRP-78) & 3 & 0 & $\mathrm{X}$ \\
\hline Trypsin inhibitor & Inter- $\alpha$-trypsin inhibitor heavy chain $\mathrm{H} 1$ isoform $\mathrm{X} 1$ (predicted) & 3 & 0 & $\mathrm{X}$ \\
\hline Trypsin & Anionic trypsin precursor & 3 & 0 & \\
\hline Complement activation & Collectin-10 precursor & 3 & 0 & \\
\hline Lipoprotein metabolism & Apolipoprotein E isoform X1 (predicted) & 3 & 0 & $\mathrm{X}$ \\
\hline Protease & Cytosolic non-specific dipeptidase isoform X1 (predicted) & 3 & 0 & \\
\hline Growth factor & Insulin-like growth factor II isoform X1 (predicted) & 3 & 0 & \\
\hline Unknown/Unspecific & Protein HP-25 homolog 2 precursor & 3 & 0 & $\mathrm{X}$ \\
\hline \multirow[t]{3}{*}{ Immune response/coagulation } & Antithrombin-III precursor & 0 & 3 & $\mathrm{X}$ \\
\hline & Coagulation factor XIII B chain precursor & 0 & 3 & \\
\hline & $\beta$-2-microglobulin (predicted) & 0 & 3 & $\mathrm{X}$ \\
\hline \multirow[t]{3}{*}{ Structural protein } & Keratin, type I cytoskeletal 19 & 0 & 4 & $\mathrm{X}$ \\
\hline & Keratin, type II cytoskeletal 4 & 0 & 4 & \\
\hline & Villin-1 & 0 & 4 & \\
\hline Cell motility/adhesion & Tubulointerstitial nephritis antigen-like isoform $\mathrm{X} 1$ & 0 & 5 & \\
\hline Lipoprotein metabolism & Apolipoprotein C-III-like (predicted) & 0 & 4 & \\
\hline Enzyme & Phospholipase A2, membrane associated precursor & 0 & 3 & \\
\hline Incretin & Gastric inhibitory polypeptide isoform X1 (predicted) & 0 & 3 & \\
\hline Milk protein & Alpha-S2-casein precursor & 0 & 3 & $\mathrm{X}$ \\
\hline DNA binding & $\zeta$-crystallin isoform X1 & 0 & 3 & \\
\hline Protease inhibitor & Serpin A3-8 precursor & 0 & 3 & $\mathrm{X}$ \\
\hline
\end{tabular}

Figure 5. Fold change analysis and protein identification of serum protein ratios between 8- and 0-h time points that differed between treatment groups $(\mathrm{n}=38)$. Treatments were assigned in pairs of newborn calves fed either heat-treated colostrum $\left(60 \mathrm{~min}\right.$ at $\left.60^{\circ} \mathrm{C}, \mathrm{H} ; \mathrm{n}=5\right)$ or a paired raw sample that was refrigerated immediately until feeding within $24 \mathrm{~h}$ after harvest $(\mathrm{R} ; \mathrm{n}=5)$. The $\mathrm{y}$-axis depicts the number of pairs with $\geq 1.5$-fold change between pairs and the direction of fold change in $\mathrm{H}$ vs. R. (Negative values show pairs with a negative fold change; positive values show pairs with a positive fold change.) The minimum number of pairs with a fold change of $\geq 1.5$ was set at 3 . 


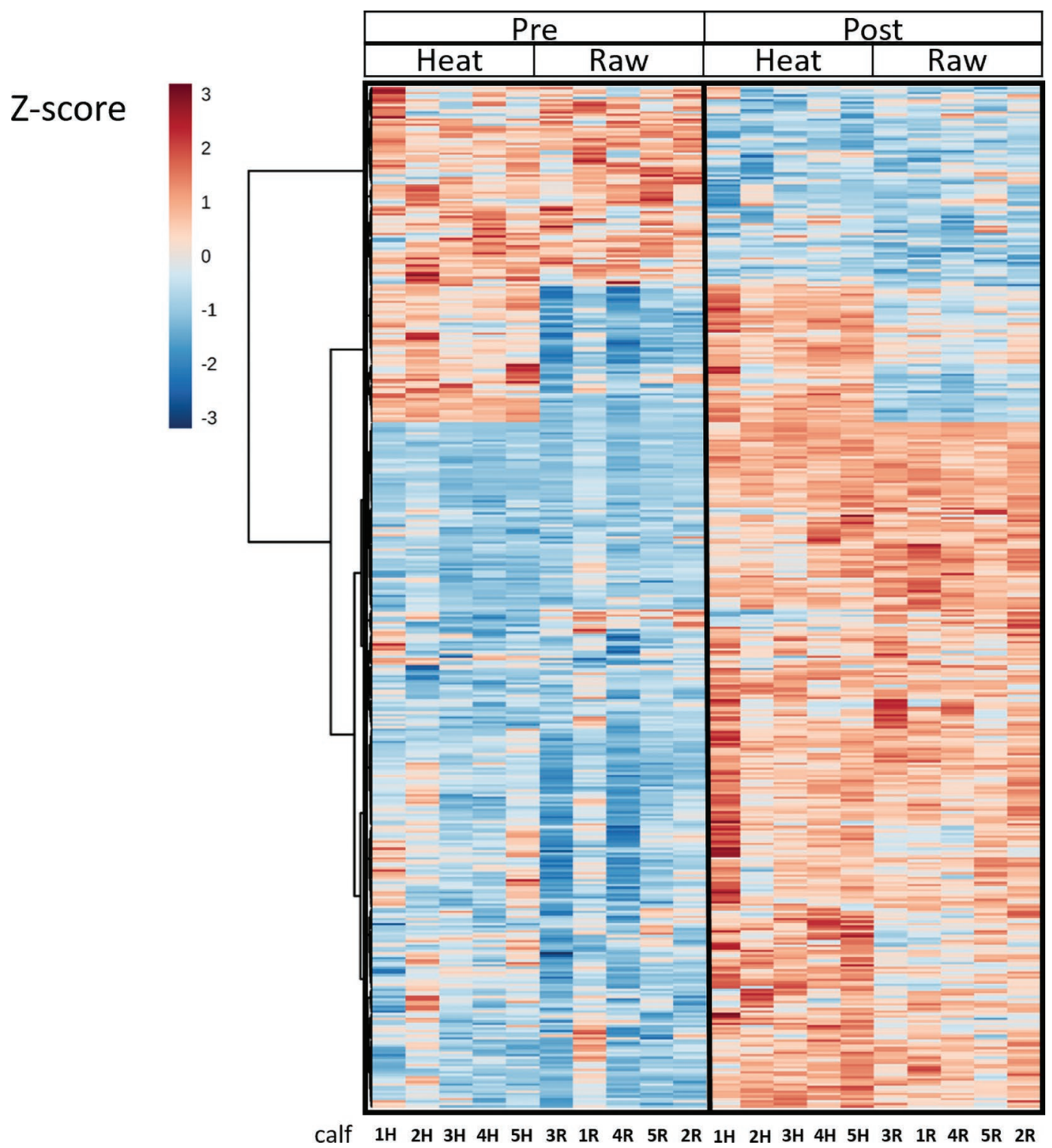

Figure 6. Hierarchical clustering (measured by Euclidean distance and using a Ward clustering algorithm) shown as a heatmap depicting all features identified by 2 -way ANOVA at $P$-value $<0.05$, adjusted for false discovery rate. Analysis of variance was conducted for calves fed heat-treated $(\mathrm{H} ; \mathrm{n}=5)$ or raw $(\mathrm{R} ; \mathrm{n}=5)$ colostrum and their serum proteins at $0 \mathrm{~h}$ (Pre) and $8 \mathrm{~h}$ (Post) relative to colostrum feeding.

colostrum (Mann et al., 2020) did not translate into differences in the calves.

Correlations of serum Brix percentage and STP refractometer readings were near perfect and confirmed the described high agreement between these 2 measurements in neonatal calf serum (Hernandez et al., 2016). Correlations of Brix percentage with $\operatorname{IgG}$ and $\operatorname{IgA}$ concentrations were moderate compared with previous studies. This may be attributable to our smaller sample size and the associated greater variability in the data set. Hernandez et al. (2016) used over 300 serum samples and found stronger correlations compared with serum IgG concentrations measured by RID for serum Brix percentage and STP refractometry, respectively ( $\mathrm{r}$ $=0.79$ and 0.82). Deelen et al. (2014) found correlations of $\mathrm{r}=0.93$ for both comparisons in 400 serum samples. The concentrations of IgG and IgA correlated moderately with each other and to a similar extent as their respective concentrations in the colostrum that was fed (Mann et al., 2020). The difference in IgA amount fed in colostrum did not translate into a significant difference in serum concentrations. Nevertheless, this difference may be of biological importance, because the role of IgA lies primarily in the intestinal lumen and mucosa, 
where they neutralize enterotoxins, exert antimicrobial properties, and inhibit invasion of microorganisms into the mucosal epithelia (Hurley and Theil, 2011).

We were particularly interested in insulin and IGF-I serum concentrations due to the observed differences in heat-treated compared with raw colostrum (Mann et al., 2020). Heat-treated colostrum had a $22 \%$ decreased insulin concentration compared with raw colostrum (Mann et al., 2020). Despite a lower oral intake in insulin, calves fed heat-treated colostrum experienced increased insulin concentrations in plasma, regardless of the absence of a difference in circulating glucose concentrations at the same time points. This finding is inconsistent with a systemic uptake of insulin, and the available literature confirms that absorption into the bloodstream is unlikely at physiological concentrations (Grütter and Blum, 1991). Results of our study therefore support the hypothesis that local and systemic insulin concentrations must be interpreted independently. Systemic insulin secretion is primarily stimulated by response to nutrients sensed through the gut, the resulting increases in incretin hormones, and by systemic glucose absorption (Nauck and Meier, 2018). At this time, we cannot be certain of the exact cause for the higher systemic insulin response in calves fed heat-treated colostrum; however, this effect is likely related to a higher gastric inhibitory polypeptide (GIP) response in this group, as will be further discussed.

Concentrations of IGF-I increased at $8 \mathrm{~h}$ after colostrum feeding in both groups, but no difference was detected between the treatments. In colostrum, heat treatment led to a median decline in IGF-I concentrations by approximately 10\% (Mann et al., 2020), but this did not translate to a difference in the calves. This is not surprising, considering that increased circulating IGF-I concentrations after colostrum feeding are likely of endogenous hepatic origin (Cordano et al., 2000; Hammon et al., 2000) rather than due to intestinal absorption (Vacher et al., 1995).

\section{Time-Dependent Changes in the Neonate Serum Proteome}

The serum proteome of calves in both groups before and $8 \mathrm{~h}$ after colostrum ingestion differed greatly, with 261 proteins that increased and 67 proteins that decreased in abundance between the 2 time points. This initial finding was particularly intriguing to us, as our

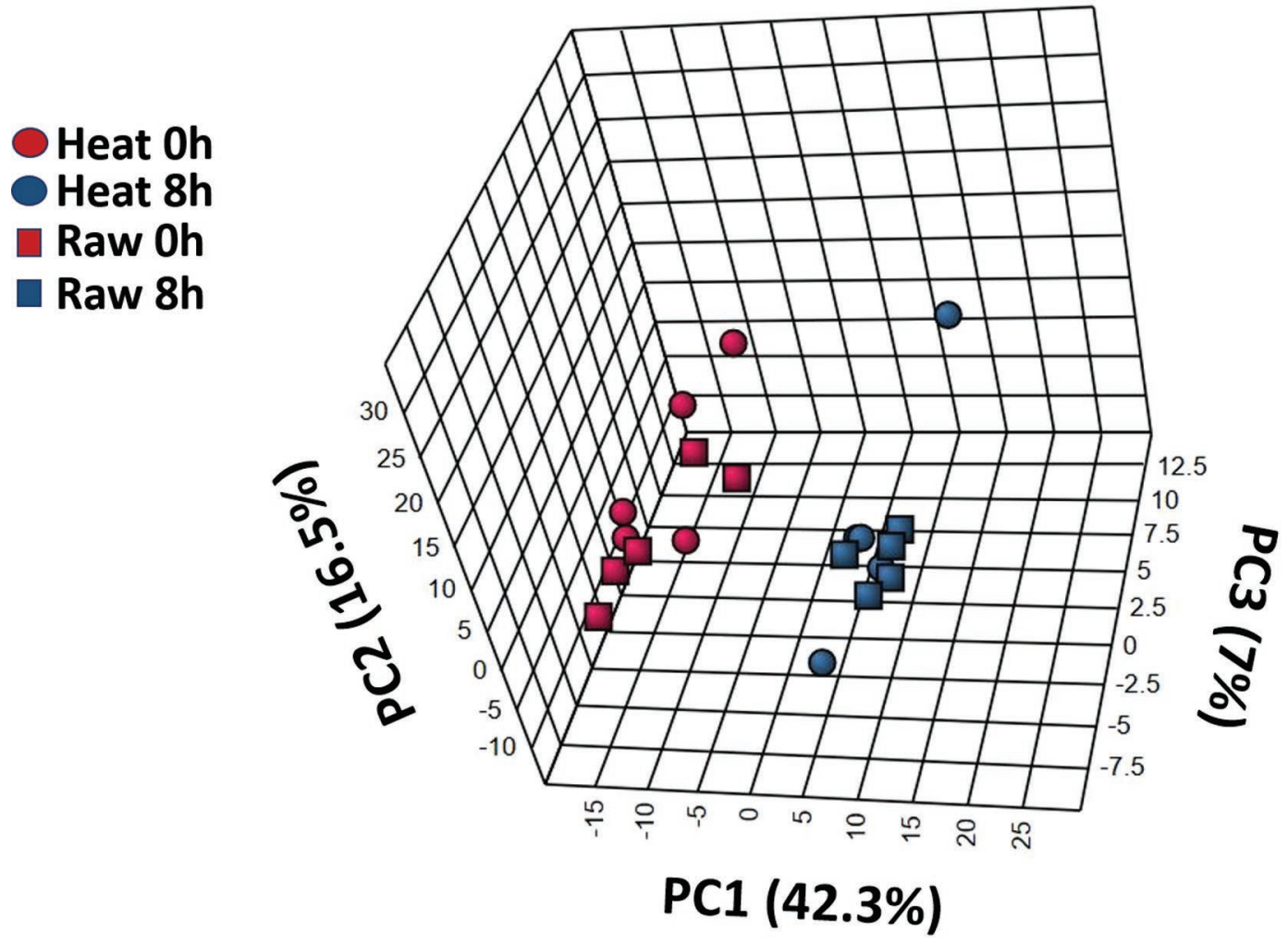

Figure 7. Scatterplot of the eigenvectors of principal component (PC) 1 against 2 and 3 shows clear separation between pairs before and after colostrum ingestion. The first PC explained $42.32 \%$ of the variability of the data and shows separation between time points 0 and 8 h relative to feeding of heat-treated (Heat; $\mathrm{n}=5$ ) or raw (Raw; $\mathrm{n}=5$ ) colostrum. 
Mann et al.: COLOSTRUM, HEAT TREATMENT, AND CALF SERUM PROTEOME

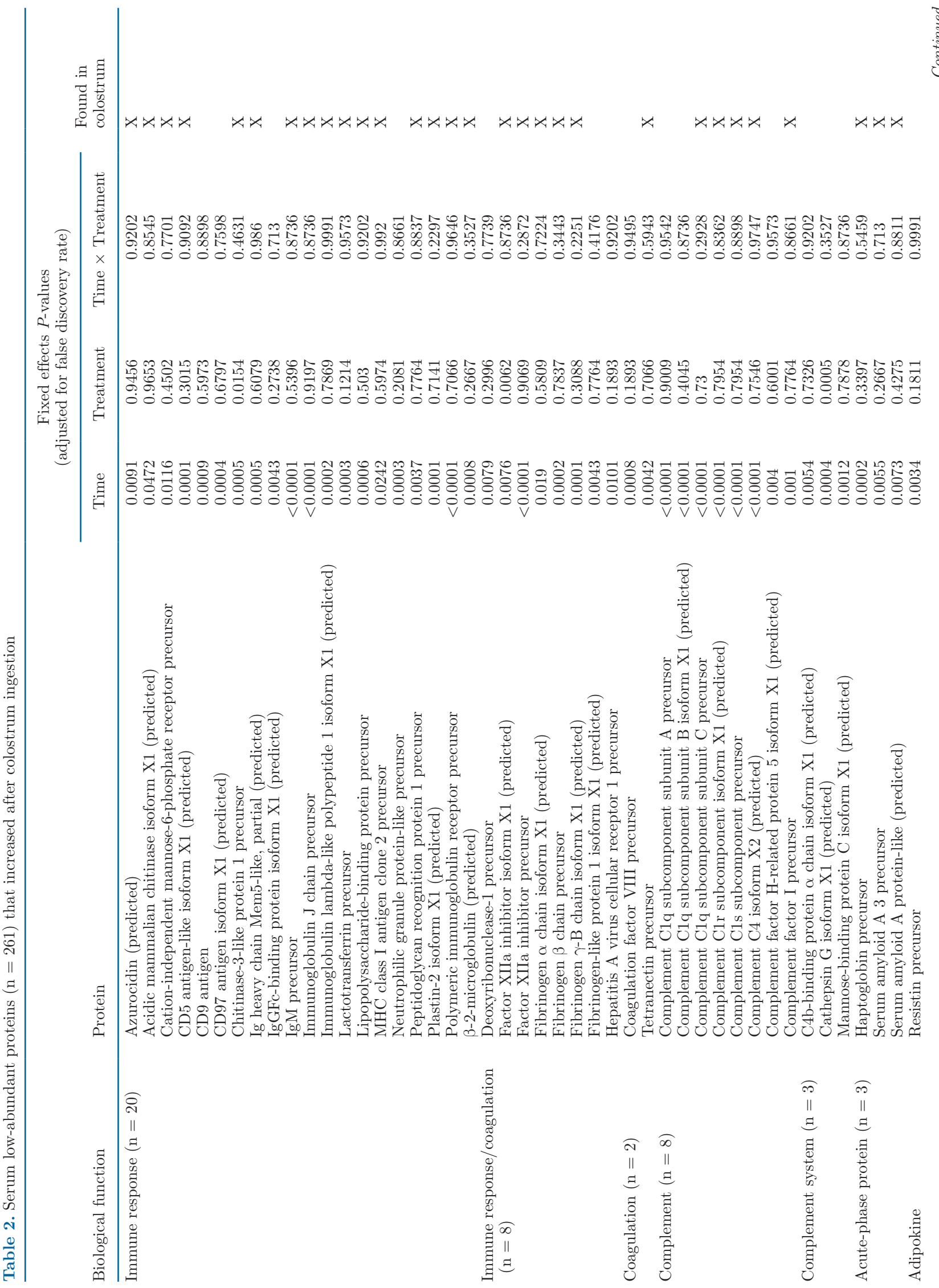




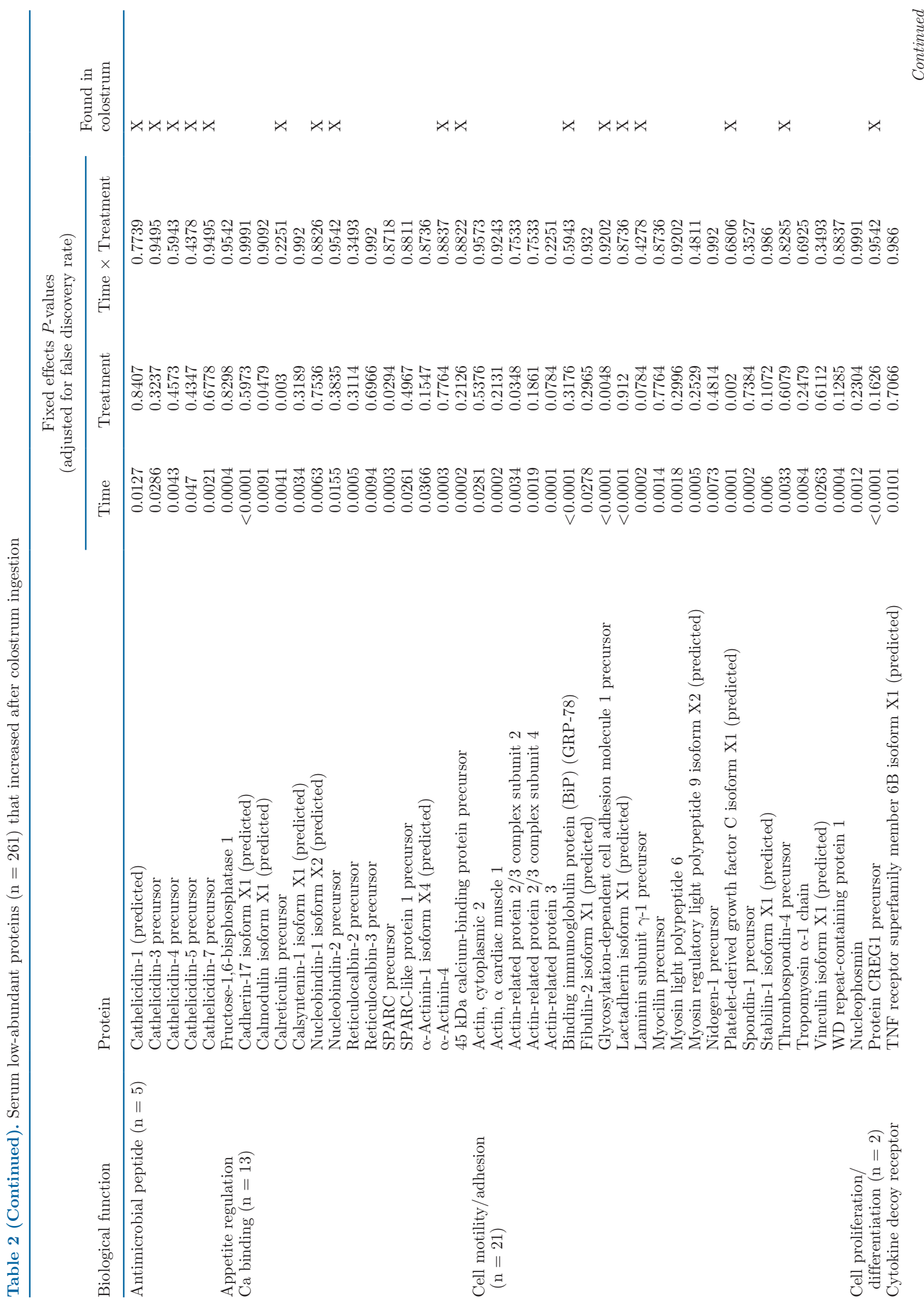




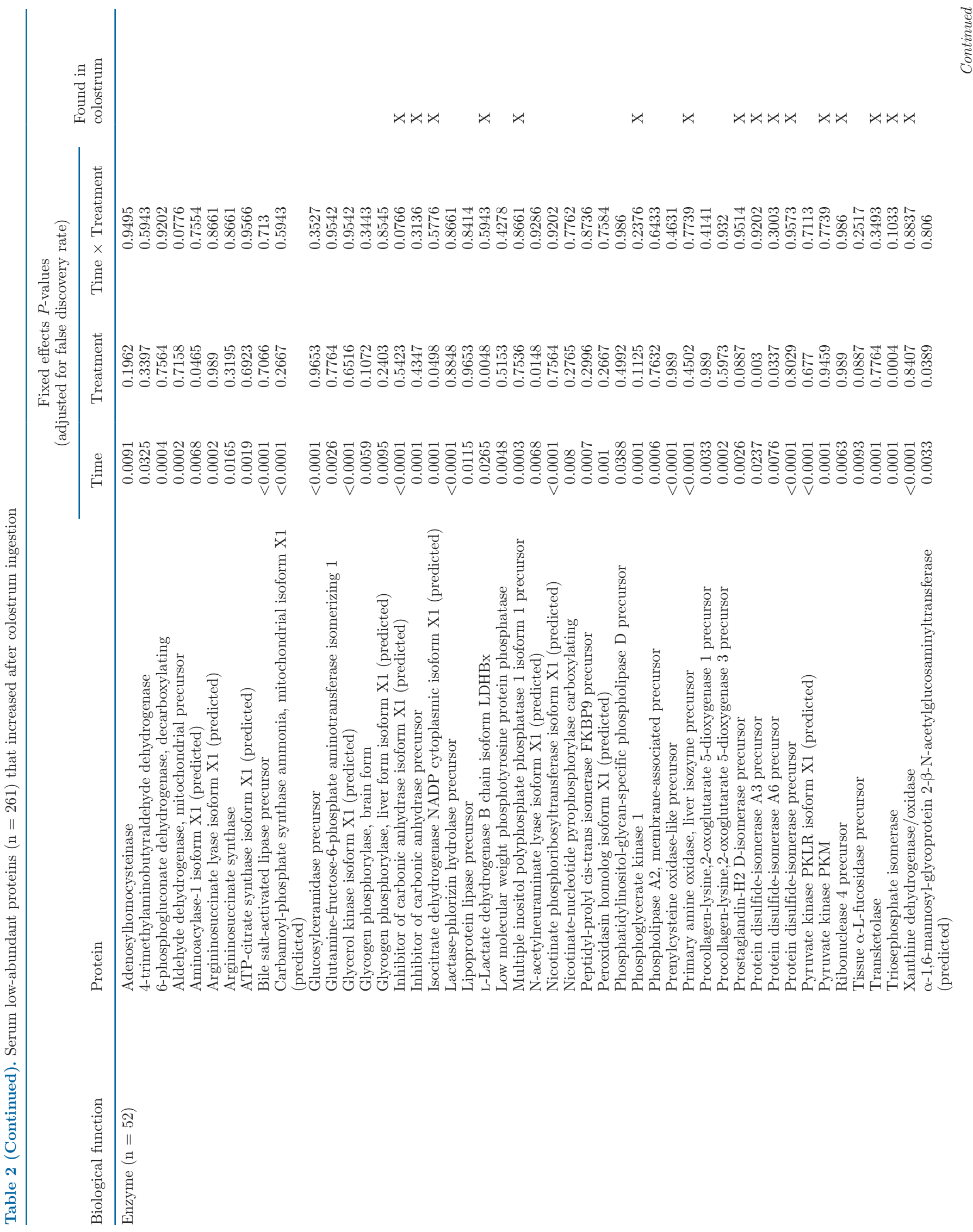




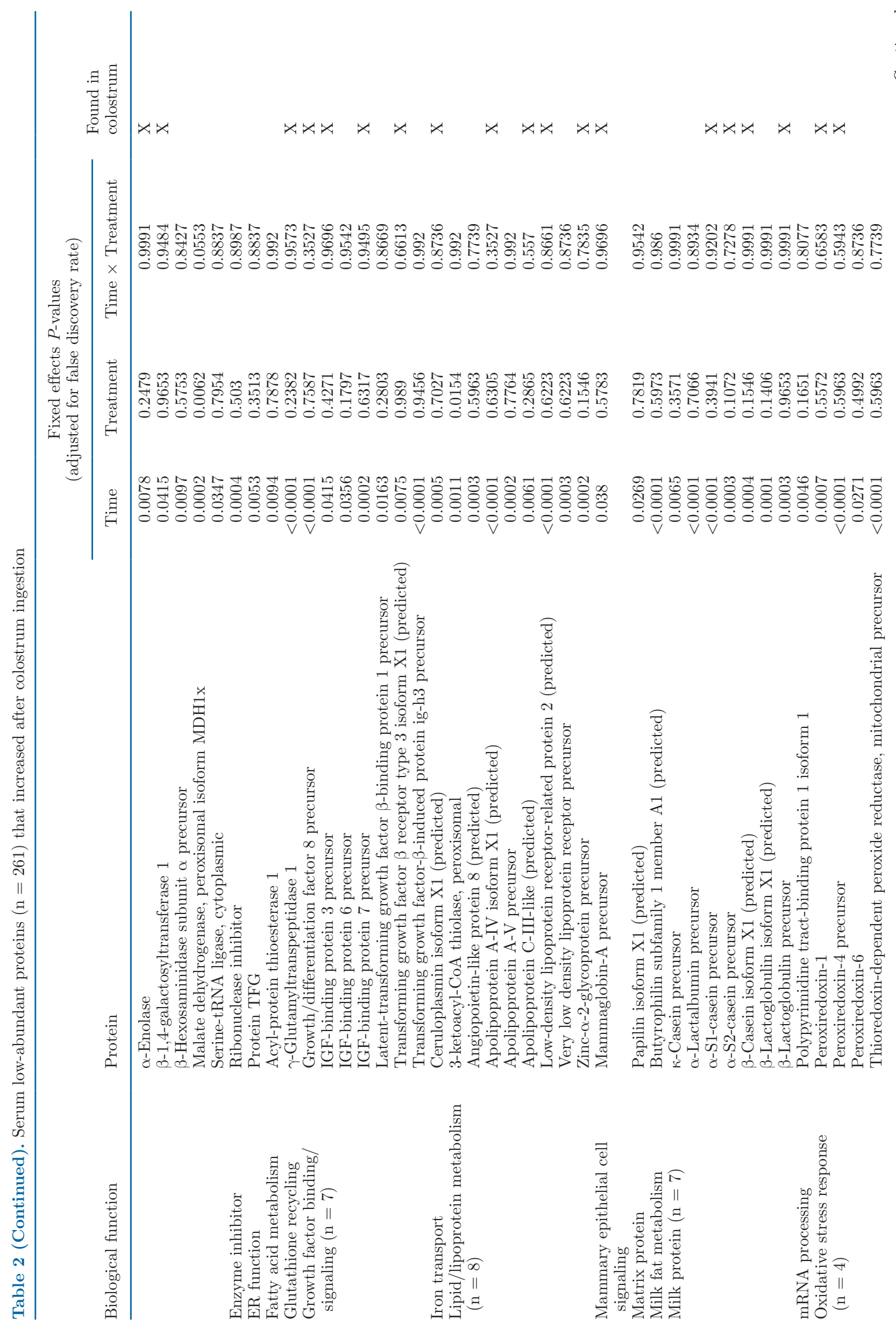




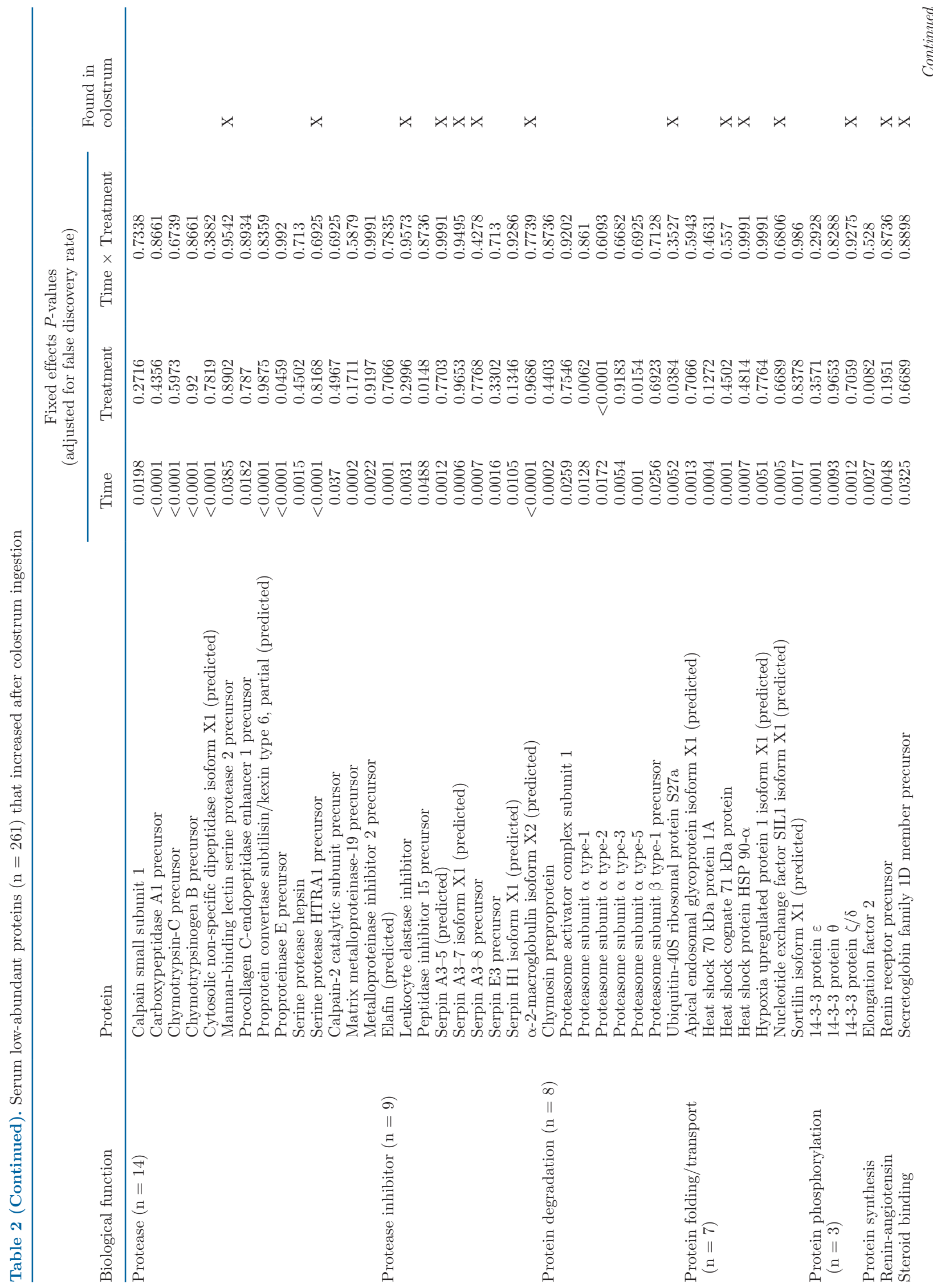




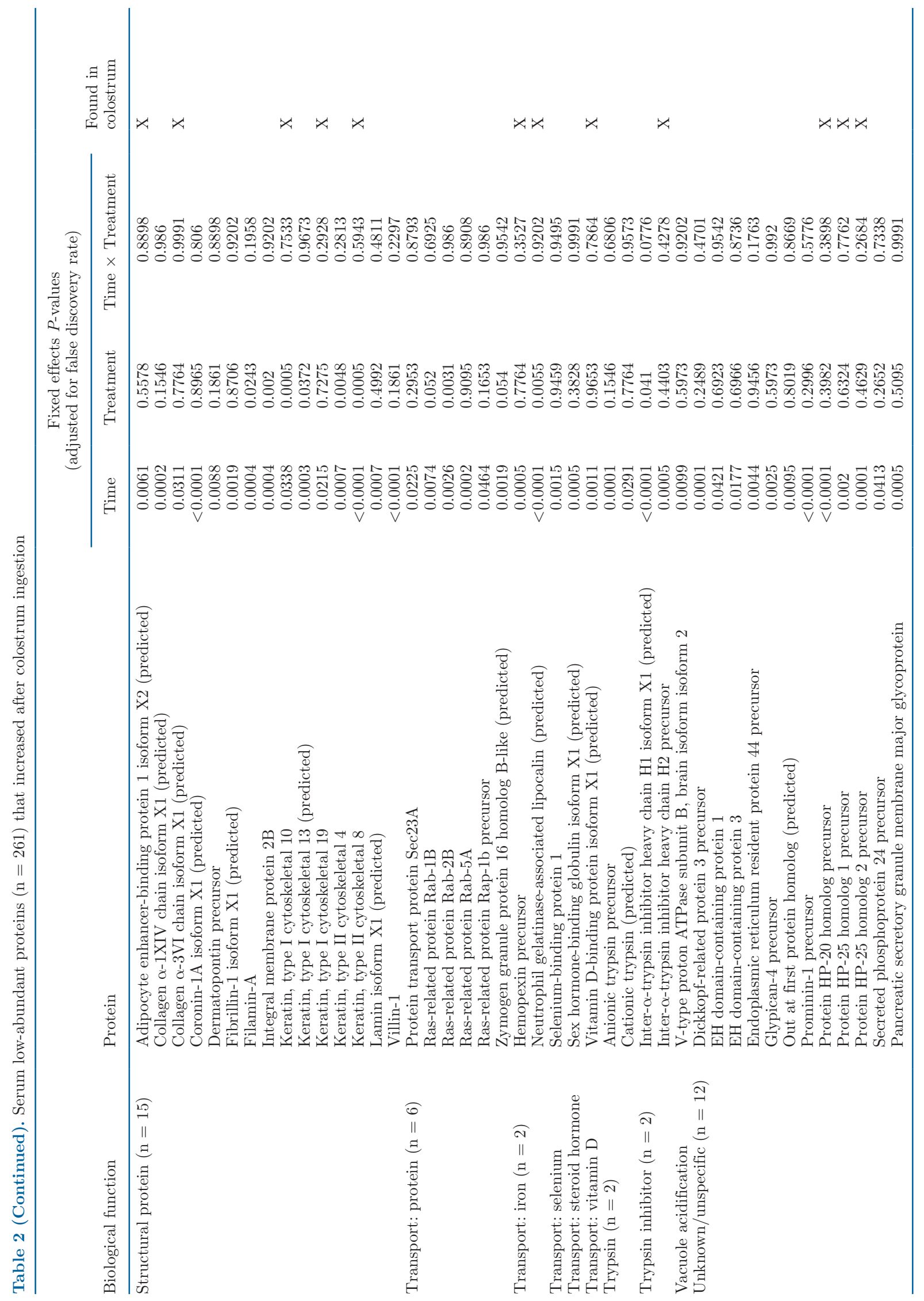




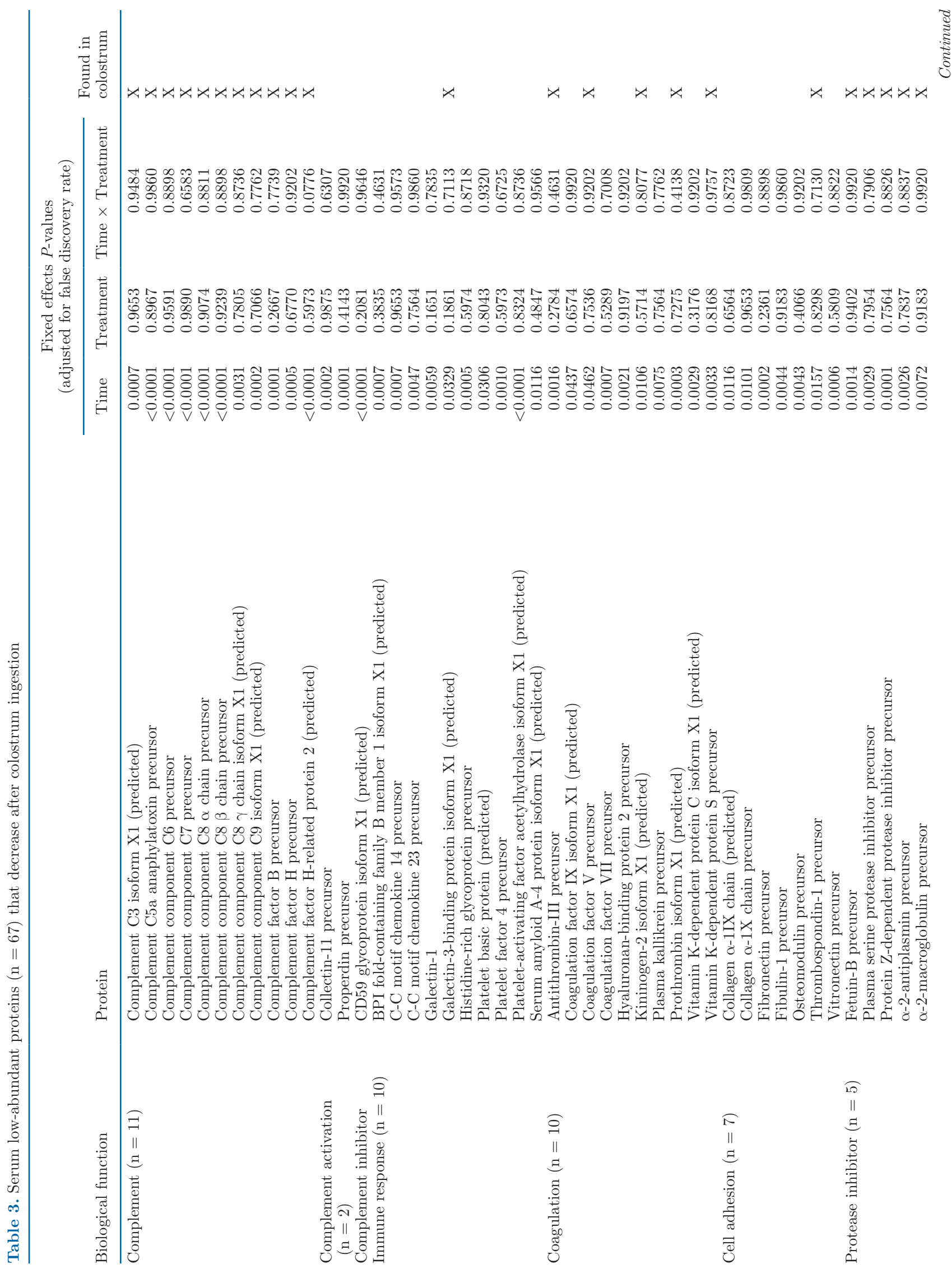




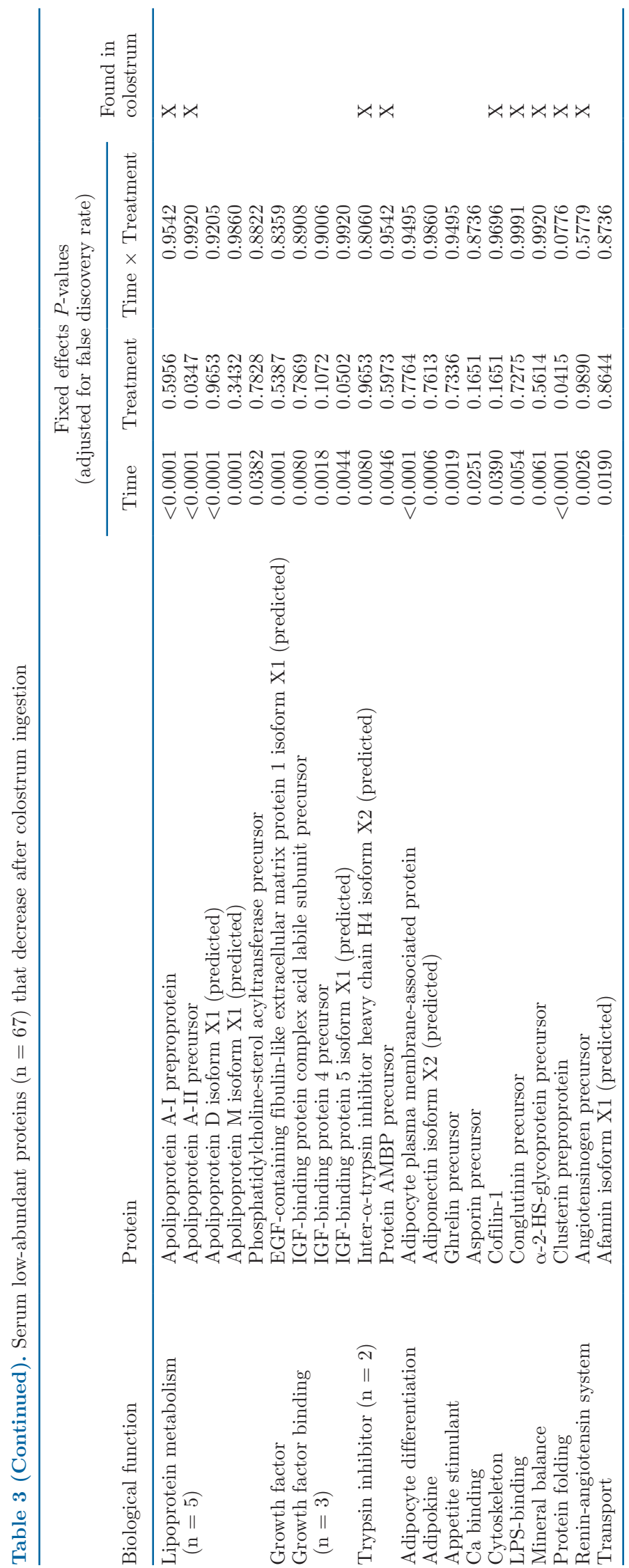

main objective was to identify proteins that change in abundance before and after colostrum feeding, and our secondary goal was to investigate possible differences in the serum proteome between calves fed raw or heattreated colostrum.

Of the proteins that increased in abundance, 109 (41\%) had also been identified in the colostrum samples that were fed to these calves (Mann et al., 2020). It is possible that increased abundance of at least these same proteins is due to systemic uptake from the intestine; however, it is also possible that these are derived partially or exclusively from endogenous production. Proteins that were identified in both colostrum and serum belong particularly to classes of proteins involved in immune response or coagulation, the antimicrobial peptide class of cathelicidins, the classical complement pathway, growth factors, protease inhibitors, acute phase proteins, and milk proteins. The serum appearance, but not the absorption, of many immunologically active factors (other than Ig) following colostrum feeding has been well described (Stelwagen et al., 2009; Hernández-Castellano et al., 2014), and this supports the important role of colostrum in establishing early immunocompetence beyond transfer of Ig in neonates.

Compared with Ig, the role of antimicrobial peptides in colostrum and circulation of the newborn calf has received relatively little attention. The presence of several different cathelicidins has been demonstrated in bovine colostrum and milk (Nissen et al., 2017; Curone et al., 2018). In humans, characterized antimicrobial actions of this group of proteins include direct pathogen killing and endotoxin binding (Ramanathan et al., 2002). Cathelicidins can be produced in the lactating mammary epithelium, and their contribution to the anti-infectious properties of milk has been demonstrated in humans (Murakami et al., 2005).

\section{Serum Complement}

Interestingly, many of the serum proteins that decreased in abundance after feeding and were identified in colostrum (Mann et al., 2020) belong to the alternative complement activation pathway (factor B), are part of the membrane attack complex (C5 to C9), or are inhibitors of the alternative complement pathway (factor H; Ogundele, 1999). In contrast, proteins involved in the classical activation pathway $(\mathrm{C} 1 \mathrm{q}, \mathrm{r}, \mathrm{s}$, and $\mathrm{C} 4$ ) increased in abundance. The classical pathway is activated mainly by Ig complexes, whereas the alternative pathway is activated directly by antigen in the absence of antibodies (Ogundele, 1999). Both pathways lead to C3 cleavage for activation, and both merge and form an identical membrane attack complex (Ogundele, 1999). Due to this role, C3 is a central molecular figure in 
complement activation (Culbertson, 1978). A decrease in C3 concentration of the newborn after colostrum ingestion has previously been described (Mueller et al., 1983). We suspect an overall net loss of complement components already present in neonate serum occurs due to entry of bacteria or bacterial cell wall components into circulation and activation of the alternative complement pathway. This consumption may include previously absorbed complement components from colostrum. Evidence suggests that complement activity is present in neonatal calves before colostrum feeding, and that its activity rapidly increases in the first days of life when calves are fed colostrum compared with those that are colostrum-deprived (Barta et al., 1972). Complement in human breast milk likely contributes to resistance against infection (Ogundele, 1999). This relationship has not been investigated in depth in bovine neonates, despite confirmation that complement components in colostrum have bactericidal activity and that such activity can be abolished due to heat inactivation at $56^{\circ} \mathrm{C}$ for 15 min (Brock et al., 1975).

\section{Changes in Serum Proteome Associated with Heat Treatment and Their Relationship to Colostrum Proteome}

Compared with the effect of time (before or after colostrum feeding), fewer serum proteins differed in abundance between the group of calves fed raw colostrum versus those fed heat-treated colostrum. Serum proteins that showed decreased abundance in calves fed heat-treated colostrum included several enzymes, such as trypsin inhibitor, fibrinogen, and the proteins involved in cellular protein transport and folding. Among these enzymes were representatives of those involved in glycolysis or glycogenolysis. The majority of these enzymes were not identified in colostrum or, if identified, did not differ between raw and heat-treated colostrum samples. It is therefore more plausible that the decrease in abundance in calves fed heat-treated colostrum was caused by a difference in endogenous enzyme production following colostrum feeding. This could be due to a difference in available enzyme substrates in circulation, rather than a direct relationship with a decreased enzyme concentration in heat-treated colostrum. The bovine neonate relies partially on endogenous glucose production from glycogenolysis and gluconeogenesis (mainly from lactate and amino acids), in addition to fatty acid oxidation and, to a lesser extent, ketogenesis, as reviewed by Hammon et al. (2012). This change in metabolism was reflected in the large number of enzymes that increased in abundance in both groups after colostrum feeding.
The striking differences in complement components in heat-treated colostrum (lower abundance in membrane attack complex proteins and classical complement pathway proteins) were not translated into an appreciable difference in the serum of calves. It is possible that our sample size was too small to detect such differences if they exist, or that the difference was masked by the presence of a relatively higher concentration of complement in serum irrespective of colostrum intake. Fetal bovine serum contains complement concentrations lower than those of adults (Triglia and Linscott, 1980), and feeding of colostrum significantly increases complement activity within a day after feeding (Barta et al., 1972). Our findings raise questions whether colostral complement is of biological significance for the newborn calf and whether it has a particular importance locally in the gut or systemically.

Fewer proteins showed increased abundance in calves fed heat-treated colostrum. Interestingly, the incretin GIP increased in these calves. This protein is secreted by intestinal endocrine cells in response to ingested nutrients, particularly glucose and fat (Nauck and Meier, 2018). The function of GIP is to stimulate a robust systemic insulin release in response to the signals from $\mathrm{K}$ cells in the upper gastrointestinal tract (Nauck and Meier, 2018). To our knowledge, no other data are available describing incretin response after initial colostrum feeding or specifically in response to heat-treated colostrum or milk in neonatal calves. In humans, Holder pasteurization was shown to increase glucose concentrations in colostrum, an effect possibly attributable to molecular changes that increase the amount of glucose released from polymers (Ley et al., 2011). Furthermore, it was observed that heat treatment of milk to $55^{\circ} \mathrm{C}$ and $65^{\circ} \mathrm{C}$ for 30 min significantly increased lactase activity and thereby increased glucose concentration in milk (Jiménez-Guzmán et al., 2002). Although bovine colostrum contains a lower percentage of lactose compared with mature milk, it also contains additional sugars such as oligosaccharides (McGrath et al., 2016). The concentration of several sialylated oligosaccharides numerically increased due to heat treatment in a single sample (Fischer et al., 2018). Those authors speculated that release of these oligosaccharides from colostral protein and fat components due to heat treatment affected substrate availability. We did not quantify glucose in colostrum and can only hypothesize that the observed GIP effect could have been caused by an increase in carbohydrate availability and possibly glucose uptake throughout the upper intestine, and that this caused the significantly higher and more prolonged systemic insulin response in calves fed heat-treated colostrum. 


\section{Limitations}

Several limitations should be considered when interpreting this data. First, we analyzed only initial changes in the serum proteome several hours after feeding. The bovine intestine is permeable beyond the first $12 \mathrm{~h}$ of life (Pletts et al., 2018), and therefore continued absorption of proteins and systemic effects are possible. We targeted an early time point to avoid a dilution effect through ad libitum milk feeding, which began after the 8-h sampling, and because we wanted to capture changes in certain proteins that may already start to decrease at this time. We used stringent data filtering and analysis settings, and only analyzed features that were detected in all samples, to reduce the possibility of spurious results driven by outliers. This may have resulted in a lower number of identified features, but it increases our confidence in the presented results.

Furthermore, we did identify potential candidates for further testing but were unable to clearly demonstrate that changes in the proteome were due to intestinally absorbed proteins rather than to endogenous production by the neonate. Due to ethical concerns about withholding colostrum from neonates, a colostrumdeprived or delayed feeding group was not included in this study. Although colostrum delay or deprivation would have allowed us to better differentiate between absorbed and secreted proteins, it was not of interest to us in the present study, as the importance of early and sufficient feeding of high-quality colostrum for the health of preweaning calves is undebatable. Delay or deprivation of colostrum also would not have allowed us to conclude with certainty that proteins appearing in circulation are taken up from the colostrum. To do so, proteins would have to be labeled in colostrum and traced to the calf's circulation after feeding. Likewise, we did not explore local effects in the gut of the neonate, as we focused on systemically circulating proteins in this study, but we have identified proteins of interest, particularly complement and cathelicidins, that should be investigated further regarding their relevance to innate immune function in the neonatal gut.

Administration of colostrum via esophageal feeder may have caused different effects on the serum proteome of calves after feeding than those expected after suckling from the dam or bottle feeding. However, we are unable to evaluate whether such differences exist. Finally, we chose to analyze serum samples rather than plasma samples. Therefore, certain circulating components of blood would have been removed due to clotting of the sample. Here we prioritized being able to better analyze LAP in the absence of fibrin aggregates at the cost of detecting proteins involved in coagulation.

\section{CONCLUSIONS}

The intent of the presented work was to explore the possible differences in Ig transfer, insulin and IGF-I concentrations, and the serum proteome in calves that were fed either heat-treated or raw colostrum. Whereas Ig transfer was unaffected by treatment, a prolonged increase of insulin concentrations after feeding was found in calves fed heat-treated colostrum that was lower in colostral insulin. A possible explanation could be the higher concentrations of the incretin GIP. The serum proteome differed drastically before and after colostrum intake, with an increase in the abundance of many nonIg immunologically active factors that were also found in colostrum, suggesting that these could have colostral origin and contribute to the critical and rapid establishment of immunocompetence of the neonate. Changes in serum abundance of complement proteins suggest early activation of the alternative complement pathway. Fewer differences in abundance of proteins were found between calves fed raw vesus heat-treated colostrum, but lower abundance of certain metabolic enzymes were observed in calves fed heat-treated colostrum.

\section{ACKNOWLEDGMENTS}

We greatly acknowledge the commercial dairy farm and farm personnel who assisted with this project. We thank the Endocrinology Laboratory of the Animal Health Diagnostic Center of Cornell University (Ithaca, NY), and Suzanne Klaessig (Ithaca, NY), for their valuable technical assistance with sample preparation and analysis. This work was supported by the Institute of Biotechnology Seed Grant Program of Cornell University (S. Mann). We thank the Proteomics Facility of Cornell University for providing mass spectrometry data and NIH SIG 1S10OD017992-01 grant support for the Orbitrap Fusion mass spectrometer. The authors have not stated any conflicts of interest.

\section{REFERENCES}

Altomare, A., E. Fasoli, M. Colzani, X. M. Paredes Parra, M. Ferrari, F. Cilurzo, C. Rumio, L. Cannizzaro, M. Carini, P. G. Righetti, and G. Aldini. 2016. An in depth proteomic analysis based on ProteoMiner, affinity chromatography and nano-HPLC-MS/MS to explain the potential health benefits of bovine colostrum. J. Pharm. Biomed. Anal. 121:297-306. https://doi.org/10.1016/j .jpba.2016.01.013.

Barta, O., V. Barta, and D. G. Ingram. 1972. Postnatal development of bactericidal activity in serum from conventional and colostrumdeprived calves. Am. J. Vet. Res. 33:741-750.

Baumrucker, C. R., M. H. Green, and J. W. Blum. 1994. Effects of dietary rhIGF-I in neonatal calves on the appearance of glucose, insulin, D-xylose, globulins and $\gamma$-glutamyl transferase in blood. Domest. Anim. Endocrinol. 11:393-403. https://doi.org/10.1016/ 0739-7240(94)90011-6. 
Brock, J. H., F. Ortega, and A. Pineiro. 1975. Bactericidal and haemolytic activity of complement in bovine colostrum and serum: effect of proteolytic enzymes and ethylene glycol tetraacetic acid (EGTA). Ann. Immunol. (Paris) 126C:439-451.

Bush, L. J., and T. E. Staley. 1980. Absorption of colostral immunoglobulins in newborn calves. J. Dairy Sci. 63:672-680. https://doi .org/10.3168/jds.S0022-0302(80)82989-4.

Chong, J., O. Soufan, C. Li, I. Caraus, S. Li, G. Bourque, D. S. Wishart, and J. Xia. 2018. MetaboAnalyst 4.0: Towards more transparent and integrative metabolomics analysis. Nucleic Acids Res. 46(W1):W486-W494. https://doi.org/10.1093/nar/gky310.

Conneely, M., D. P. Berry, J. P. Murphy, I. Lorenz, M. L. Doherty, and E. Kennedy. 2014. Effect of feeding colostrum at different volumes and subsequent number of transition milk feeds on the serum immunoglobulin G concentration and health status of dairy calves. J. Dairy Sci. 97:6991-7000. https://doi.org/10.3168/jds.2013-7494.

Cordano, P., H. M. Hammon, C. Morel, A. Zurbriggen, and J. W. Blum. 2000. mRNA of insulin-like growth factor (IGF) quantification and presence of IGF binding proteins, and receptors for growth hormone, IGF-I and insulin, determined by reverse transcribed polymerase chain reaction, in the liver of growing and mature male cattle. Domest. Anim. Endocrinol. 19:191-208. https:// doi.org/10.1016/S0739-7240(00)00073-4.

Culbertson, M. R. 1978. Bovine hemostatic and complement systems: I. Ontogenetic studies; II. Fetal response to bacterial endotoxin. $\mathrm{PhD}$ thesis, University of California, Davis.

Curone, G., J. Filipe, P. Cremonesi, E. Trevisi, M. Amadori, C. Pollera, B. Castiglioni, L. Turin, V. Tedde, D. Vigo, P. Moroni, A. Minuti, V. Bronzo, M. F. Addis, and F. Riva. 2018. What we have lost: Mastitis resistance in Holstein Friesians and in a local cattle breed. Res. Vet. Sci. 116:88-98. https://doi.org/10.1016/j .rvsc.2017.11.020.

Deelen, S. M., T. L. Ollivett, D. M. Haines, and K. E. Leslie. 2014. Evaluation of a Brix refractometer to estimate serum immunoglobulin $\mathrm{G}$ concentration in neonatal dairy calves. J. Dairy Sci. 97:3838-3844. https://doi.org/10.3168/jds.2014-7939.

Donovan, D. C., A. J. Reber, J. D. Gabbard, M. Aceves-Avila, K. L. Galland, K. A. Holbert, L. O. Ely, and D. J. Hurley. 2007. Effect of maternal cells transferred with colostrum on cellular responses to pathogen antigens in neonatal calves. Am. J. Vet. Res. 68:778-782. https://doi.org/10.2460/ajvr.68.7.778.

Elizondo-Salazar, J. A., and A. J. Heinrichs. 2009. Feeding heat-treated colostrum to neonatal dairy heifers: Effects on growth characteristics and blood parameters. J. Dairy Sci. 92:3265-3273. https: //doi.org/10.3168/jds.2008-1667.

Fahey, M. J., A. J. Fischer, M. A. Steele, and S. L. Greenwood. 2020. Characterization of the colostrum and transition milk proteomes from primiparous and multiparous Holstein dairy cows. J. Dairy Sci. https://doi.org/10.3168/jds.2019-17094.

Fischer, A. J., N. Malmuthuge, L. L. Guan, and M. A. Steele. 2018. Short communication: The effect of heat treatment of bovine colostrum on the concentration of oligosaccharides in colostrum and in the intestine of neonatal male Holstein calves. J. Dairy Sci. 101:401-407. https://doi.org/10.3168/jds.2017-13533.

Furman-Fratczak, K., A. Rzasa, and T. Stefaniak. 2011. The influence of colostral immunoglobulin concentration in heifer calves' serum on their health and growth. J. Dairy Sci. 94:5536-5543. https:// doi.org/10.3168/jds.2010-3253.

Gelsinger, S. L., and A. J. Heinrichs. 2017. Comparison of immune responses in calves fed heat-treated or unheated colostrum. J. Dairy Sci. 100:4090-4101. https://doi.org/10.3168/jds.2016-12010.

Godden, S. M., J. E. Lombard, and A. R. Woolums. 2019. Colostrum management for dairy calves. Vet. Clin. North Am. Food Anim. Pract. 35:535-556. https://doi.org/10.1016/j.cvfa.2019.07.005.

Grütter, R., and J. W. Blum. 1991. Insulin and glucose in neonatal calves after peroral insulin and intravenous glucose administration. Reprod. Nutr. Dev. 31:389-397. https://doi.org/10.1051/rnd: 19910405.

Hammon, H. M., J. Steinhoff-Wagner, J. Flor, U. Schonhusen, and C. C. Metges. 2013. Lactation Biology Symposium: Role of colostrum and colostrum components on glucose metabolism in neona- tal calves. J. Anim. Sci. 91:685-695. https://doi.org/10.2527/jas $.2012-5758$.

Hammon, H. M., J. Steinhoff-Wagner, U. Schonhusen, C. C. Metges, and J. W. Blum. 2012. Energy metabolism in the newborn farm animal with emphasis on the calf: Endocrine changes and responses to milk-born and systemic hormones. Domest. Anim. Endocrinol. 43:171-185. https://doi.org/10.1016/j.domaniend.2012.02.005.

Hammon, H. M., I. A. Zanker, and J. W. Blum. 2000. Delayed colostrum feeding affects IGF-I and insulin plasma concentrations in neonatal calves. J. Dairy Sci. 83:85-92. https://doi.org/10.3168/ jds.S0022-0302(00)74859-4.

Hernandez, D., D. V. Nydam, S. M. Godden, L. S. Bristol, A. Kryzer, J. Ranum, and D. Schaefer. 2016. Brix refractometry in serum as a measure of failure of passive transfer compared to measured immunoglobulin $\mathrm{G}$ and total protein by refractometry in serum from dairy calves. Vet. J. 211:82-87. https://doi.org/10.1016/j.tvjl.2015 .11 .004 .

Hernández-Castellano, L. E., A. M. Almeida, M. Ventosa, A. V. Coelho, N. Castro, and A. Arguello. 2014. The effect of colostrum intake on blood plasma proteome profile in newborn lambs: Low abundance proteins. BMC Vet. Res. 10:85. https://doi.org/10 .1186/1746-6148-10-85.

Hernández-Castellano, L. E., A. Arguello, A. M. Almeida, N. Castro, and E. Bendixen. 2015. Colostrum protein uptake in neonatal lambs examined by descriptive and quantitative liquid chromatography-tandem mass spectrometry. J. Dairy Sci. 98:135-147. https: //doi.org/10.3168/jds.2014-8143.

Hurley, W. L., and P. K. Theil. 2011. Perspectives on immunoglobulins in colostrum and milk. Nutrients 3:442-474. https://doi.org/ $10.3390 /$ nu3040442.

Jiménez-Guzmán, J., A. E. Cruz-Guerrero, G. Rodríguez-Serrano, A. López-Munguía, L. Gómez-Ruiz, and M. García-Garibay. 2002. Enhancement of lactase activity in milk by reactive sulfhydryl groups induced by heat treatment. J. Dairy Sci. 85:2497-2502. https://doi.org/10.3168/jds.S0022-0302(02)74332-4.

Johnson, J. L., S. M. Godden, T. Molitor, T. Ames, and D. Hagman. 2007. Effects of feeding heat-treated colostrum on passive transfer of immune and nutritional parameters in neonatal dairy calves. J. Dairy Sci. 90:5189-5198. https://doi.org/10.3168/jds.2007-0219.

Ley, S. H., A. J. Hanley, D. Stone, and D. L. O'Connor. 2011. Effects of pasteurization on adiponectin and insulin concentrations in donor human milk. Pediatr. Res. 70:278-281. https://doi.org/ 10.1203/PDR.0b013e318224287a.

Mann, S., G. Curone, T. L. Chandler, P. Moroni, J. Cha, R. Bhawal, and S. Zheng. 2020. Heat treatment of bovine colostrum: I. Effects on bacterial and somatic cell counts, immunoglobulin, insulin, and IGF-I concentrations, as well as the colostrum proteome. J. Dairy Sci. 103:9368-9383. https://doi.org/10.3168/jds.2020-18618.

McGrath, B. A., P. F. Fox, P. L. H. McSweeney, and A. L. Kelly. 2016. Composition and properties of bovine colostrum: A review. Dairy Sci. Technol. 96:133-158. https://doi.org/10.1007/s13594 -015-0258-x.

McGuire, T. C., N. E. Pfeiffer, J. M. Weikel, and R. C. Bartsch. 1976. Failure of colostral immunoglobulin transfer in calves dying from infectious disease. J. Am. Vet. Med. Assoc. 169:713-718.

McGuirk, S. M., and M. Collins. 2004. Managing the production, storage, and delivery of colostrum. Vet. Clin. North Am. Food Anim. Pract. 20:593-603. https://doi.org/10.1016/j.cvfa.2004.06.005.

Mueller, R., J. T. Boothby, E. J. Carroll, and L. Panico. 1983. Changes of complement values in calves during the first month of life. Am. J. Vet. Res. 44:747-750.

Murakami, M., R. A. Dorschner, L. J. Stern, K. H. Lin, and R. L. Gallo. 2005. Expression and secretion of cathelicidin antimicrobial peptides in murine mammary glands and human milk. Pediatr. Res. 57:10-15. https://doi.org/10.1203/01.PDR.0000148068.32201 .50 .

Nauck, M. A., and J. J. Meier. 2018. Incretin hormones: Their role in health and disease. Diabetes Obes. Metab. 20:5-21. https://doi .org/10.1111/dom.13129.

Nissen, A., P. H. Andersen, E. Bendixen, K. L. Ingvartsen, and C. M. Rontved. 2017. Colostrum and milk protein rankings and ratios of 
importance to neonatal calf health using a proteomics approach. J. Dairy Sci. 100:2711-2728. https://doi.org/10.3168/jds.2016-11722.

Ogundele, M. O. 1999. Inhibitors of complement activity in human breast-milk: a proposed hypothesis of their physiological significance. Mediators Inflamm. 8:69-75. https://doi.org/10.1080/ 09629359990559.

Pletts, S., J. Pyo, S. He, D. Haines, L. Guan, and M. Steele. 2018. PSI19 effect of extended colostrum feeding on serum IgG in newborn calves. J. Anim. Sci. 96(Suppl. 3):182. https://doi.org/10.1093/ jas/sky404.396.

Quigley, J. D. 3rd, and J. J. Drewry. 1998. Nutrient and immunity transfer from cow to calf pre- and postcalving. J. Dairy Sci. 81:2779-2790. https://doi.org/10.3168/jds.S0022-0302(98)75836 -9 .

Raboisson, D., P. Trillat, and C. Cahuzac. 2016. Failure of passive immune transfer in calves: A meta-analysis on the consequences and assessment of the economic impact. PLoS One 11:e0150452. https: //doi.org/10.1371/journal.pone.0150452.

Ramanathan, B., E. G. Davis, C. R. Ross, and F. Blecha. 2002. Cathelicidins: Microbicidal activity, mechanisms of action, and roles in innate immunity. Microbes Infect. 4:361-372. https://doi.org/10 .1016/S1286-4579(02)01549-6.

Reber, A. J., A. Lockwood, A. R. Hippen, and D. J. Hurley. 2006. Colostrum induced phenotypic and trafficking changes in maternal mononuclear cells in a peripheral blood leukocyte model for study of leukocyte transfer to the neonatal calf. Vet. Immunol. Immunopathol. 109:139-150. https://doi.org/10.1016/j.vetimm.2005.08 .014 .

Shulman, R. J. 1990. Oral insulin increases small intestinal mass and disaccharidase activity in the newborn miniature pig. Pediatr. Res. 28:171-175. https://doi.org/10.1203/00006450-199008000-00018.

Steinhoff-Wagner, J., S. Gors, P. Junghans, R. M. Bruckmaier, E. Kanitz, C. C. Metges, and H. M. Hammon. 2011. Intestinal glucose absorption but not endogenous glucose production differs between colostrum- and formula-fed neonatal calves. J. Nutr. 141:48-55. https://doi.org/10.3945/jn.110.128652.

Stelwagen, K., E. Carpenter, B. Haigh, A. Hodgkinson, and T. T. Wheeler. 2009. Immune components of bovine colostrum and milk. J. Anim. Sci. 87(suppl_13):3-9. https://doi.org/10.2527/jas.2008 $-1377$.

Stilwell, G., and R. C. Carvalho. 2011. Clinical outcome of calves with failure of passive transfer as diagnosed by a commercially available IgG quick test kit. Can. Vet. J. 52:524-526.

Tacoma, R., S. L. Gelsinger, Y. W. Lam, R. A. Scuderi, D. B. Ebenstein, A. J. Heinrichs, and S. L. Greenwood. 2017. Exploration of the bovine colostrum proteome and effects of heat treatment time on colostrum protein profile. J. Dairy Sci. 100:9392-9401. https:// doi.org/10.3168/jds.2017-13211.

Triglia, R. P., and W. D. Linscott. 1980. Titers of nine complement components, conglutinin and C3b-inactivator in adult and fetal bovine sera. Mol. Immunol. 17:741-748. https://doi.org/10.1016/ 0161-5890(80)90144-3.

Urbaniak, G. C., and S. Plous. 2012. Research Randomizer (Version 4.0). Accessed June 2018. http://www.randomizer.org/form.htm.

Urie, N. J., J. E. Lombard, C. B. Shivley, C. A. Kopral, A. E. Adams, T. J. Earleywine, J. D. Olson, and F. B. Garry. 2018. Preweaned heifer management on US dairy operations: Part I. Descriptive characteristics of preweaned heifer raising practices. J. Dairy Sci. 101:9168-9184. https://doi.org/10.3168/jds.2017-14010.

Vacher, P. Y., G. Bestetti, and J. W. Blum. 1995. Insulin-like growth factor I absorption in the jejunum of neonatal calves. Biol. Neonate 68:354-367. https://doi.org/10.1159/000244256.

Yang, S., X. Li, X. Liu, X. Ding, X. Xin, C. Jin, S. Zhang, G. Li, and H. Guo. 2018. Parallel comparative proteomics and phosphoproteomics reveal that cattle myostatin regulates phosphorylation of key enzymes in glycogen metabolism and glycolysis pathway. Oncotarget 9:11352-11370. https://doi.org/10.18632/oncotarget .24250

Yang, Y., X. Qiang, K. Owsiany, S. Zhang, T. W. Thannhauser, and L. Li. 2011. Evaluation of different multidimensional LC-MS/MS pipelines for isobaric tags for relative and absolute quantitation (iTRAQ)-based proteomic analysis of potato tubers in response to cold storage. J. Proteome Res. 10:4647-4660. https://doi.org/ $10.1021 /$ pr200455s.

Zhang, Z., Y. H. Ahmed-Braimah, M. L. Goldberg, and M. F. Wolfner. 2019. Calcineurin-dependent protein phosphorylation changes during egg activation in Drosophila melanogaster. Mol. Cell. Proteomics 18(Suppl. 1):S145-S158. https://doi.org/10.1074/mcp .RA118.001076.

\section{ORCIDS}

S. Mann (1) https://orcid.org/0000-0003-1806-1154

G. Curone $\odot$ https://orcid.org/0000-0001-6352-0036

T. L. Chandler @ https://orcid.org/0000-0001-6299-9436

A. Sipka ๑ https://orcid.org/0000-0002-8646-824X

S. Zhang (1) https://orcid.org/0000-0001-8206-1007 